\title{
A Transnational Witness to "Other" Stories of Suffering: Encountering Czech Memory in Selected Works by the French Novelist Sylvie Germain
}

\author{
Clare Horáčková ${ }^{1}$ (D)
}

Received: 22 October 2015/Accepted: 23 December 2015/Published online: 13 January 2016

(C) The Author(s) 2016. This article is published with open access at Springerlink.com

\begin{abstract}
The French novelist Sylvie Germain spent 6 years in Czechoslovakia before, during, and after the Velvet Revolution of 1989 that ended four decades of oppressive totalitarian rule in that country. As a result of her stay, Germain produced four texts that are imbued with painful Czech stories and memories of both the Holocaust and the Communist era. This study examines the inscription of Germain's encounter with the (Czech) other into her writing through tropes of exile and dispossession, of the suffering or wounded body, and of illness. Although Germain did not experience either the Holocaust or totalitarianism at first hand, and has moreover no claim to a Czech heritage, I posit that her work can nonetheless be interpreted as a transnational witness to the suffering of the (Czech) other. Using theories of the self and other, as well as theories of exile and of the narration of illness, I discuss how Germain's work negotiates the fine line between an appropriation of the stories of the other and an ethical responsibility to respond to other stories of pain.
\end{abstract}

Keywords Sylvie Germain · Contemporary French literature · Transnational witnessing · Illness narratives · The body

\section{Writing from an "Other" Perspective}

The critically acclaimed French novelist and essayist Sylvie Germain spent 6 years in the Czech capital of Prague from 1986 until 1993 and produced four texts in response to her encounter with the Czech "other". Each of these texts is set in the traumatic years of twentieth-century Czechoslovakia, collectively spanning the Second World War and Holocaust as well as the oppressions of the Communist

Clare Horáčková

c.horackova@exeter.ac.uk

1 University of Exeter, Exeter, UK 
regime which held power in the country from 1948 until the Velvet Revolution of 1989. Those four decades were marked by confiscations of property, censorship, surveillance, exiles, imprisonment, and executions, as well as the everyday restrictions of freedom of life inside the closed borders of a totalitarian country. All four of Germain's Czech texts portray characters who have been disinherited or alienated by the events of recent Czech history. The first to be published was the short novel La Pleurante des rues de Prague (Germain 1992). Set in late twentiethcentury Prague, the story charts the 12 apparitions of a huge, limping female figure (la Pleurante, or the weeping woman) who reappears to the French narrator in different spots throughout Prague, evoking a series of sorrowful memories of the history of Prague. The second text in the Czech group, Immensités, reflects on the fate of dissidents, including the protagonist Prokop, living in the constrictive confines of the Communist regime (Germain 1993a). The central character of the third novel, Éclats de sel, is the equally disillusioned Ludvík, who goes into exile from his homeland to escape the regime (Germain 1996). The fourth text, a prose reflection on the life and works of a Bohemian poet and artist in whom Germain found a source of inspiration, is the eponymously titled Bohuslav Reynek à Petrkov: Un nomad en sa demeure (Germain 1998a). ${ }^{1}$ Germain records the regime's confiscation of Reynek's beloved home and the censorship of his writing which meant that much of his work was published only posthumously. This study uses a body of critical work relating to the relationship between the self and other and to the narration of painful experience in order to analyse these texts (with a close focus on La Pleurante and Éclats) as a form of transnational witness to Central European stories and memories of the troubled events of the latter half of the twentieth century.

Before embarking on close analysis of the texts, it is important to emphasise the fact that Germain's Czech texts constitute a departure from her own national context as she embraces the stories of suffering and dispossession that she encountered during her stay in Prague. As a French writer with no claim to a Czech heritage, Germain is writing from an external viewpoint about the traumatic stories of an "other" nation, a perspective which raises the important question as to whether Germain's representation of Czech stories of pain constitutes an appropriation of someone else's story. Geoffrey Hartman's concept of becoming a "witness by adoption" therefore underpins my analysis of Germain's work as a transnational response to Czech pain (Hartman 1996). In her work on the transmission of the past, Marianne Hirsch draws on Hartman's concept to describe what she calls the work of "postmemory" as "an intersubjective transgenerational space of remembrance" which may transcend the confines of "familial inheritance" (p. 10 in Hirsch 2001). Hirsch calls, moreover, for closer investigation into the ways in which the

\footnotetext{
${ }^{1}$ English translations of the three works of fiction have been published under the following titles: $\mathrm{La}$ Pleurante des rues de Prague as The Weeping Woman on the Streets of Prague (Germain 1993b); Immensités as Infinite Possibilities (Germain 1998b); and Éclats de sel as Invitation to a Journey (Germain 2003). Bohuslav Reynek: Un nomad en sa demeure, meaning "Bohuslav Reynek: A Nomad in his Abode", has not been published in translation. For consistency, and as there are no translations available of the interviews or secondary material cited in relation to Germain's work, all translations provided in this study are my own.
} 
transferential processes of "identification with the victim or witness of trauma" may affect not only familial groups but also "other, less proximate groups" (p. 10). In comparison with a number of Czech writers, such as the exiled novelist Milan Kundera or the poet Petr Král, whose work about the difficult histories of their homeland has been published in French, Germain clearly occupies a "less proximate" position both nationally and linguistically in relation to Czech histories. I argue, however, that her writing constitutes an empathetic "identification" with these "other" stories of twentieth-century dispossession which she has said that she feels bound by "une nécessité profonde intérieure" [a deep-seated inner need] to narrate (p. 336 in Magill 1999). My analysis of Germain's Czech writings responds to Hirsch's call to widen our understandings of the possibilities of "witness[ing] by adoption" by suggesting that the "identification" of which Hirsch speaks can transcend not only generational but also national divisions through this process of empathetic witnessing to the pain of others who may not be a part of our immediate familial or even national group. This is a form of witnessing that corresponds to Shoshana Felman's understanding of the almost involuntary call or "appointment" to witness that, she observes, is often felt by those who find themselves in a position of observing the trauma or illness of others (p. 2 in Felman 1992). Felman writes that the event necessitating testimony is always in some way "the scandal of an illness" (p. 4), and I shall argue that Germain's Czech writings are a form of transnational witness to what she too terms "le scandale" of the twentieth-century events that are portrayed in her Czech writings as a societal sickness (p. 73 in Germain 1991).

Beyond simply considering Germain's texts as an (albeit empathetic) third-party record of the stories of others, this study examines whether Germain attempts to inscribe herself (and perhaps, by implication, the reader) into the other's story of suffering. Alain Goulet, who has published widely on Germain's work, has written of the intersection of personal and collective sorrows in her texts, saying that in $\mathrm{La}$ Pleurante, "les souffrances personnelles, intimes, de l'auteur [...] prennent leur sens et leur valeur à s'y trouver partagées avec celles des autres" ([the personal and intimate sorrows of the author... are endowed with meaning and value as they merge with the sorrows experienced by others] p. 245 in Goulet 2008). Taking Goulet's comment as a starting point, I will consider how Germain uses the very specific context of painful Czech histories as a lens through which to project both her own experience and the wider questions of pain and dispossession that preoccupy her throughout her œuvre. My argument for Germain's writing as a transnational "witness by adoption" is, however, inflected with an awareness of the ethical issues that have been foregrounded by recent discussions about the appropriation of the trauma of the other by means of vicarious or third-party narration. In his discussion of Holocaust narratives, Colin Davis warns that, "[w]e should not have the arrogance to assume that we can share some part of what happened to the victims. [...] we do not participate in or co-own the other's trauma" (p. 20 in Davis 2011). Although he acknowledges that we are ethically "bound to attempt" to respond in some manner to traumatic stories of the other (p. 22), Davis insists that we should not assume that we can understand the other's pain, pointing out that, " "your story is never my story" " [...]. There is no [...] secure bridge 
between our experience and that of other people" (p. 21, citing p. 92, Cavarero 2000), and in the course of this study I will highlight ways in which Germain prioritises the incomprehensibility of the other's experience so that her work bears witness to "other" traumas without claiming them as her own.

In understanding Germain's attraction to the alterity of Central Europe and Czechoslovakia, it should be noted that she has spoken in interview of a particular childhood interest in "l'histoire du yiddish et [...] les mythologies scandinaves et slaves" ([the history of Yiddish and... Scandinavian and Slavic mythologies] p. lvi in Diatkine 1998). This would later be heightened by a love of Slavic and Central European writers (see Magill 1999), and each of her own Czech texts constitutes an intertextual response to a wide range of works of Czech art and literature (see Poulouin 2008; Roche 2008). This web of cross-cultural referentiality constitutes part of Germain's appreciation of and encounter with what Julia Kristeva has described as "la fertilité de l'autre" ([the fertility of the other] p. 111 in Kristeva 1988); in this case, of course, the emphasis is on the Czech other. Germain's intertextual references bring to our attention a large number of Czech writers and artists whose work was suppressed by censorship, or who were either imprisoned, marginalized, or lost their lives in the course of the dramatic political events of Czech history. The inclusion of these references is not merely a means of sharing an appreciation of a country that Germain has come to know and enjoy, but also a more profound attempt to address the historical dispossessions and silencings that she became aware of during her stay. Her Czech writing may therefore be interpreted as part of a wider process of bringing to greater attention the stories of what Celia Hawkesworth, in her volume of Central European women's writing, has called "the other Europe" because of its "invisibility" to Western eyes during the Communist years (p. 199 in Hawkesworth 2001). Ursula Keller's essay "Writing Europe" similarly identifies a need to address the "unequal distribution" of attention paid to Central and Eastern Europe, and this is a need which also underpins my analysis of Germain's Czech works (p. 11 in Keller 2004).

Germain's growing interest in alterity would be further nourished by her studies at the Sorbonne under the Jewish Lithuanian philosopher Emmanuel Levinas. Since it is widely acknowledged that Germain has been significantly influenced by his work on the concepts of self and other, my discussion in this study of Germain's work as an embodiment of her response to the Czech other necessarily explores this influence. ${ }^{2}$ I particularly draw on Levinas's understanding of the ethical responsibility that is forged between the self and the other by their meeting, an event which Levinas variously describes in terms of "la face à face" or "la rencontre" ([face to face or encounter] Levinas 1971). I propose that this concept is embedded in the very structure of Germain's Czech writings, and my analysis will show that it central to understanding her work as an encounter with the other.

Critical studies of Germain's work to date are both numerous and highly varied in the direction of their enquiry, yet almost unanimously take as a starting point the

\footnotetext{
2 As Toby Garfitt has pointed out, Germain's doctoral thesis was heavily influenced by the philosophy of Levinas; many of her published essays refer to his work; and her novels are marked by his thinking on the concepts of self and other. See Garfitt (2008).
} 
premise that the trope of "le mal" [evil] underlies and unifies her work (see Goulet 2006; Dotan 2009; Garfitt 2003), a position that is borne out in Germain's own claim that "[a]ll my books are about the problem of evil" (p. 13 in Young 1993). ${ }^{3}$ Whether she is writing about France or Czechoslovakia, Germain is particularly preoccupied with the depravities of the twentieth century, which she describes as "un siècle de plomb et de crasse et de sang" ([a century of heaviness and filth and blood] p. 63 in Germain 1992), and with the loss of meaning that she says has troubled humanity since Auschwitz. This loss of meaning is articulated as follows in Bohuslav Reynek: "Pour beaucoup, en effet, à mesure que la terre se couvre de charniers et de fosses communes, le ciel leur semble se creuser en vertigineuse fosse divine" ([For many, as the earth is engulfed by communal graves and mass burial pits, so the heavens disappear into a bewildering spiritual gulf] p. 25 in Germain 1998a). My analysis of the incomprehensibility of the other's suffering will later return to this location of loss within the mass burial pits of the Holocaust. Germain's preoccupation with the recurrence of historical "evil" is seen clearly in her early works, in which the signs of both the sufferings and wrongdoings of previous generations are often corporeally imprinted onto their descendants; an example can be seen in the case of the protagonist of her first published novel, Victor-Flandrin, who fathers multiple sets of twins; their duality symbolically embodies his own father's schizophrenia, which itself was caused by the horrors he witnessed during the wars in France and by his own wounding, which left his face divided by a scar (Germain 1985). This bodily marking-out of past sufferings is a pattern that is reflected in the central figure of her first Prague story, La Pleurante, whose limping body we shall see bears witness to centuries of suffering in Central Europe. In this manner, Germain's entire œuvre explores and bears witness to the impact of living with a legacy of painful familial and national pasts, a legacy which I will show to be marked out on the body in her writing. In her Prague novels, however, the oppression of the Czech nation during the Communist years is increasingly portrayed in terms of imagery relating to sickness, which becomes a trope in these texts for the way in which traumatic experience and memory affect both those who are directly involved, and those who, like Germain, become a witness to such stories or memories. This study therefore also intersects with a body of work describing illness and its narration in order to explore the implications of Germain's use of the metaphor of sickness as a means of representing and bearing witness to the Czech experience of totalitarian control.

\section{2 "Propulsée dans un Monde d'Horreur": Responding through the Body to the Suffering Other}

A key moment in Germain's early life was her visit at the age of eight or so to the concentration camp of Struthof-Natzweiler in Alsace, an event that she has spoken of in interview as "un choc brutal, et très profond" ([a brutal and profound shock]

\footnotetext{
${ }_{3}^{3}$ Note that Elizabeth Young's piece is based on an interview she conducted with Germain, from which she cites in English; citations here are therefore in their published English form.
} 
p. 251 in Goulet 2006), and in the face of which she found herself "arrachée au monde et propulsée dans un monde d'horreur' ([wrenched from the world and impelled into a world of horror] Pirard 1992). Germain's sensation of being brutally impelled from a childhood world of innocence into an adult world of "horreur" resonates with the biblical story of the ejection of Adam and Eve from paradise, and so carries associations of exile from the presence of God, a theme which continually intersects with her exploration of dispossession. This early experience of a spiritual sense of exile, I propose, contributes to her empathy for the Czech experience of historical dispossession. The bodily terms ("arrachée", "propulsée" [wrenched, impelled]) in which Germain describes that moment of exile suggest, moreover, that her experience was felt not only emotionally but indeed through the body, and I will argue that this corporeal awakening to the pain of others means that Germain feels bodily implicated in the (French and Central European) stories of suffering that she would later write about. This corporeal participation in the pain of others gives rise accordingly to the language of wounding and of sickness that is used throughout her work to express emotional or spiritual suffering.

Germain's personal sense of exile through her awakening, at StruthofNatzweiler, to the possibility of evil, coupled with her sense of the incomprehensibility of twentieth-century suffering, plays out in an encounter in Éclats between the alienated Ludvík and "un kiosquier" [a newspaper stall-keeper] who recounts his visit to the infamous camp of Auschwitz-Birkenau. Despite previously feeling that he had understood the events that took place there ("je croyais déjà savoir, j'avais vu et lu beaucoup de choses à ce sujet" [I thought that I already understood, I had seen and read so much about it] p. 73), the man recalls being overwhelmed by incomprehension:

Mais quand je me suis trouvé physiquement sur les lieux déserts et silencieux, tout en moi s'est effondré, comme si une faux glissait au ras de ma raison, de ma mémoire, et y tranchait toutes les idées, réflexions et connaissances que j'avais pu accumuler. Un vide s'est ouvert en moi, j'étais la proie d'un désastre intérieur, d'un brutal accès d'idiotie (p. 73).

[But when I found myself physically there on those deserted and silent grounds, everything fell away inside me, as if a scythe had sliced through my mind, through my memory, cutting away all the ideas, thoughts, and knowledge that I had accumulated. A void opened up inside me, I was overcome by an internal catastrophe, all knowledge was brutally stripped away from me.]

There is a strong parallel here between the stall-keeper's physical experience of "un désastre intérieur" [an internal catastrophe] when he was confronted with Auschwitz, and Germain's recollection of the bodily "choc brutal" of her own visit to Struthof; the man's experience is also comparably framed in terms of exile: "je me suis senti [...] irrémédiablement banni hors de la terre des hommes" ([I felt myself... eternally banished from the land of men] p. 73). To some extent, then, Germain is inscribing herself into the figure of this Czech "stall-keeper". It is also important, however, that the passage insists on the impossibility of understanding 
"la souffrance endurée en ce lieu" [the suffering endured in that place]: the man's response is characterised by sensations of "void" and of the stripping away of knowledge. This lack of comprehension intersects with Davis's position that it is ethically problematic to "even try to understand" the pain of others and particularly atrocity on the scale of the Holocaust (p. 19 in Davis 2011). This in turn supports my argument that Germain's work avoids the "arrogance" (p. 20) of appropriation, and this is a position which is carried through in the remainder of this passage as the man continues to recall his response to Auschwitz.

Confronted with this site of unimaginable horrors, the man, like Germain, undergoes a powerful bodily reaction that compels him to respond: "je serais bien tombé à genoux, mais non pour embrasser le sol, plutôt pour y cogner mon front et y frapper des poings" ([I wanted to fall to my knees, not to kiss the ground but to strike my forehead against it and beat it with my fists] p. 73). Overwhelmed by incomprehension, the man is unable to articulate a response, and yet his body speaks for him. This immediate and corporeal reaction continues after he has left the site of the concentration camp and returned to the village, where he is overcome by an unwelcome and unexpected "faim terrible" so that he gorges himself to the point of physical sickness: "Je suis revenu dans la ville d'Auschwitz et j'ai commandé à manger [...] du porc aux choux. Et puis un dessert [...] Encore du porc, et des patates [...] du poisson. Jusqu'à l'étouffement, la nausée" ([I went back into the town of Auschwitz and ordered something to eat... pork and sauerkraut. And then a dessert... More pork, some potatoes... some fish. I ate until I was stuffed, sick] p. 75). Two points can be drawn from this involuntary corporeal response: firstly, as Davis observes, absence of response in the face of such suffering or its memory is not an ethical option, since,

not to speak for those who have been silenced, not to recall or to study what happened to them in the hope of learning something from their stories, would be an act of barbarity in itself, hideously complicit with the forces which sought to eliminate them (p. 19 in Davis 2011).

The line between an "arrogant" assumption of another's pain and the "barbarity" of ignoring it is undeniably a difficult one to negotiate, and one way in which Germain shows her awareness of this ethical difficulty lies in her emphasis on the bodily, instinctive nature of response. The involuntary nature of the man's response when forced to confront the horrors of Auschwitz resonates with Germain's own "nécessité intérieure profonde" ([deep-seated inner need] p. 336 in Magill 1999) to respond textually, so that her writing is an externalisation of the compulsion to "recall" and so to avoid the "barbarity" of forgetfulness. This call to respond can be further understood in the light of Levinas's articulation, in an essay entitled "Useless Suffering", of the nature of pain and of its potential to forge relationships between otherwise unconnected human beings (Levinas 1998). Levinas tells us that "[s]uffering in the other, where it is unforgivable to me, solicits and calls me", demanding a response, which becomes in turn "suffering in me [...] a suffering for the suffering (inexorable though it may be) of someone else" (p. 94). This elicited response in the self to the suffering other gives meaning to suffering, says Levinas: "It is this attention to the suffering of the other that, through the cruelties of our 
century (despite these cruelties, because of these cruelties) can be affirmed as the very nexus of human subjectivity" (p. 94). Germain's own call to write about the suffering other (as inscribed into the stall-keeper's involuntary and corporeal reaction to Auschwitz) becomes, then, an "attention" which, far from appropriating or assuming a position of "arrogance", demonstrates a humility - a textual means of "tomb[er] à genoux" [falling to (her) knees] alongside the stall-keeper-before the incomprehensible suffering of others.

The second point that I draw from the man's involuntary physical reaction to Auschwitz relates more closely to his desire to gorge himself and his consequent sickness. His need to eat is perhaps a means of attempting to fill the emotional and spiritual void that opens up in him, and which, moreover, resonates with the images in Bohuslav Reynek of the "charniers et fosses communes" [communal graves and mass burial pits] that covered the earth during the Second World War as well as with the image of the consequent experience of a "vertigineuse fosse divine" [bewildering spiritual gulf]. Germain's configuration of this individual and collective loss of comprehension and meaning in terms of physical sickness is perhaps nowhere in her work more explicit than in the image of the man's nausea, the result of his crazed gorging: “j'ai été malade, bien sûr! J'ai dû descendre précipitamment du bus qui me ramenait vers la gare tant j'avais envie de vomir" ([I was sick, of course! I wanted to vomit so badly that I had to rush off the bus that was taking me back to the station] p. 76). These physical manifestations of the sense of exile created in Germain and in her characters by their encounter with the inconceivable reality of the concentration camp can be interpreted in conjunction with Arthur Frank's understanding that stories of illness "are told not just about the body but through it" (p. 3 in Frank 1995). In the absence of words in which he can express his horror at "la souffrance endurée en ce lieu" [the suffering endured in that place], the stall-keeper's story is told by his body so that, in Levinassian terms, "[s]uffering in the other" becomes indeed "suffering in me". His vomiting is his involuntary bodily testimony to the enormity of such suffering, rather as Germain's writing is the externalisation of her "nécessité intérieure profonde" ([deep-seated inner need] p. 336 in Magill 1999) to respond to the suffering (Czech) other.

Germain has spoken of the importance of both familial and national participation in the transgenerational legacy of the Second World War and Holocaust, saying that "[j]e me rends compte que de par leurs parents, de nombreuses personnes de ma génération sont directement héritières de cette Seconde Guerre mondiale. Cette période représente toute la jeunesse de mes parents" ([I am aware that many people of my generation feel a sense of direct inheritance of the Second World War through their parents. My parents' youth was made up of those years] p. 2 in Glaiman 2005). Germain's sense of "inheriting" the legacy of the war creates another "bridge" between her position and the Central European traumas of which she is writing. Whilst her early works engage with that legacy on largely French terms, the Czech works constitute an acknowledgement that this legacy extends beyond French or Western European borders. These texts are accordingly not simply set in Czech geographical territories: in terms of twentieth-century traumas, they persistently draw attention not to French memories but rather to Czech and Central European losses, places, people, and events, many of which may be unfamiliar to Western 
readers. Thus La Pleurante refers, for example, to specific victims of the Holocaust in Central Europe, including "un petit garçon de Terezín, qui n'était plus depuis longtemps [...] qui ne devint jamais un homme, mais qu'on livra aux cendres, au vent, à la fosse, à l'oubli" ([a little boy in Terezín who died long ago... who never grew up, but was sent up in smoke, into the wind, into the pits, into oblivion] p. 50 in Germain 1992). ${ }^{4}$ In his study of Germain's incorporation of Czech historical and literary references into her writing, Gérard Poulouin draws attention to the presence, in both La Pleurante and Immensités, of the concentration camp of Terezín (which was located in the town of the same name in North Bohemia), pointing out that by retaining the Czech name in favour of the better-known German name of Theresienstadt, "[Germain] inscrit nettement ce camp dans le territoire tchèque" ([Germain inscribes this camp firmly onto Czech territory] p. 43 in Poulouin 2008).

I would add that this pattern is repeated throughout the Czech texts, which insist on locating the Holocaust in Central Europe; not in any manner as a denial of the importance of French or Western European Holocaust memory (which of course receives attention in Germain's other, French, stories), but rather, I suggest, as a means of once again signposting the immensity of the experience of the (nonWestern) other and thus, in the manner envisaged by Claire Kramsch, of "bring[ing] to light other possible meanings that have been forgotten by history or covered up by politics" (p. 103 in Kramsch 2006). As such, Germain's work reminds us that this era and the way in which it was played out across borders still demands our attention. By systematically drawing the attention of the French reader to "other" possible experiences of the twentieth century as it was played out in "the other Europe" (p. 199 in Hawkesworth 2001), Germain's writing is not "appropriating" a history that belongs to others but rather refusing to allow such stories to be "covered up"; in this manner her work redresses in part the "unequal distribution" of attention to "other" stories that has also been observed by Keller (p. 11 in Keller 2004).

The refusal to allow such stories of the other to be "covered up" is made specifically manifest, in La Pleurante, in the numerous evocations and namings of dead and forgotten victims of Czech history, whether of the Holocaust or of the Communist era. One example of this process can be seen in Germain's practice of incorporating intertextual references to marginalised Czech writers, such as the poet Jan Skácel, whose work was banned in the 1970s during a period of strict censorship, and who could publish only in "samizdat" (the Czech term for the underground distribution of dissident writings). The chapter entitled "Quatrième apparition" [Fourth apparition] cites as its epigraph a translated passage of Skácel's poetry: "Parfois il arrive que l'âme humaine pue comme le poil d'un chien mouillé./ [...] je veux que la douleur/fasse vraiment mal et qu'une larme soit une larme" ([Sometimes the human soul stinks like the fur of a wet dog./... I want pain/to feel like true pain and a teardrop to be a true teardrop] p. 37). Germain takes up Skácel's motif at the end of that chapter in a reference to the evils and suffering of the

\footnotetext{
${ }^{4}$ Note that Terezín, better known by the German name of Theresienstadt, was the largest Nazi concentration camp in Bohemia. For a summary of its history, see Martin Winstone (2010). Germain's choice of Terezín, rather than one of the more widely known camps, focuses attention on the effects of the Holocaust within Czechoslovak territory.
} 
twentieth century: “C'est que, sous ses grands airs, l'Histoire pue. Il conviendrait de le sentir, et il importe de le dire, pour que [...] l'on n'oublie pas qu'une larme pèse un poids gigantesque" ([Beneath its grand appearances, History stinks. It is important to feel this, and to speak of it, so that... we do not forget that a teardrop weighs a huge weight] p. 45). The huge weight of sorrow is of course made overtly explicit in the size of the weeping woman, since "[e]lle est immense, une géante" [she is huge, a giant], so that the physical presence of her huge body makes it difficult to ignore the "immense" weight of pain that she represents (p. 19). As well as insisting on the memory of Skácel in particular, and the losses of Czech Communism in general, this citation also provides us with a connection between, on the one hand, the corporeal response to suffering discussed above and echoed here in the word "sentir" [to feel] and, on the other hand, the need to translate that bodily reaction into speech or writing that is indicated in the words "il importe de le dire" [it is important to speak of it]: once again Germain is foregrounding the need not only to recognise the pain of others, but also to respond.

We could also note that this naming of Skácel and twenty or more other persecuted Czech writers and artists corresponds to the use of roll calls or "necrology", which Chloe Paver points out are frequently used in memorial-making in an attempt to "restor[e] individuality" to those whom the Nazi regime sought to anonymize (p. 258 in Paver 2010). ${ }^{5}$ A further example of this process of bringing the memory of the lost other to wider attention by naming them and insisting not only on the huge weight of collective loss, but also on their individual lives is found in the "ghosts" of the past who are summoned before the (French) narrator of La Pleurante. These ghostly figures are again all victims of Central European histories whose memory is intimately invoked using both personal detail about the lost life and specifically Central European metaphors and cultural references. This attention to the individual can be seen, for example, in a passage describing the memory of "une fillette aux yeux trop grands, trop sombres" [a little girl with terribly big, dark eyes] whose impoverished father "avait peint pour elle, son enfant aux pieds nus, quelques fleurs sur le mur derrière le lit" ([had painted a few flowers on the wall behind the bed for his bare-footed child] p. 68). Germain acknowledges that her textual reincarnation of the child in this apparition is inspired by a photograph taken by the Jewish Latvian photographer Roman Vischniac (p. 69). Vischniac himself was interned in a deportation camp as a "stateless person", but was released and went on to secretly record on film images of the camps in an attempt to persuade the Western world of their reality, a mission which resonates with Germain's own writing mission to return a voice to the silenced or forgotten. The flowers on the wall in Vischniac's now famous photograph, recreated in this scene by Germain, also reappear as a motif throughout the text in phrases highlighting the forgetting and silencing of such stories: "les fades roses de l'oubli"; "ces illusions de fleurs de cave"; "les roses de personne" ([the faded roses of forgetting; these dreams of flowers in the grottoes; the

\footnotetext{
5 Note that whilst Paver refers to the memorial context of National Socialism, necrology is also used in the Czech Republic in both Holocaust memorial (for example in the 80,000 Jewish names inscribed on the walls of the chapel in the Prague Ghetto, which is now a memorial and museum space) and recent memorials to the losses of the Communist era (as in the 'Memorial to the Victims of Communism', or Pomník obětem komunismu, that was unveiled in 2002 in Petřín in Prague).
} 
roses of nobody] pp. 68-70). The child is named- "Elle s'appelait Sarah" ([She was called Sarah] p. 69)—-so that she too takes her place in the memorial "roll call" created by this text; by this means, Germain continues the work of Vischniac in identifying the forgotten, bringing their individual lives into focus, and bringing them to the attention of the Western world. Paver notes that, although necrology can be an effective means of encouraging the viewer or reader to contemplate the immensity of loss, there is nevertheless a potential danger in that the use of names in list form can sometimes result in a perpetuation of the "loss of individuality that was part of the original victimization" (p. 258 in Paver 2010). She notes that one method by which memorials may overcome the tension between individualisation and anonymity entails the use of biographical detail to insist on the life story. I propose that Germain's intimate use of personal detail and anecdote, such as the flowers painted above the child's bed by her father, or the incorporation of the words of persecuted writers such as Skácel, invites us to pause and reflect on the lives lost and so insists on individual identity. In this manner, Germain's writing can be aligned with what Paver notes to be a motivating factor of the use of necrology and other methods of memorial-making, namely "to challenge the anonymization of individuals" in cases of mass murder or persecution (p. 257 in Paver 2010).

The flowers of Vischniac's work, recreated textually by Germain, also create a link with other works of Central European significance, and especially with Kundera's Le Livre du rire et de l'oubli ([The Book of Laughter and Forgetting] 1987) where "les fleurs mélancholiques de l'oubli" [the melancholoy flowers of forgetting] spring up in the cities of Central Europe in the place of monuments and statues torn down in the various cycles of what Richard S. Esbenshade has termed the "state-managed forgetting" that has plagued the region (p. 74 in Esbenshade 1995). ${ }^{6}$ The image is taken up yet again in Germain's Immensités, in a recurrent motif of "la fleur du temps qui passe" [the flower of passing time], drawn from a freedom song of the 1960s, ${ }^{7}$ which relates to Prokop's sensation of being forgotten "dans la très poussiéreuse salle d'attente de l'Histoire" ([in the very dusty waiting room of history] p. 20 in Germain 1993a). The simple image of the "fleur de l'oubli" [flower of forgetting] thus takes on a growing weight of significance as it is woven through this multi-layered metaphor, but many of the layers of meaning may remain obscure to the Western reader, or are revealed only upon close scrutiny. The complexity of the image encourages us to contemplate and engage with its possible meanings in a manner that again intersects with Levinas's call to pay attention to the other, even as we are compelled to admit that we may not comprehend the image in its entirety. Far from invalidating the process of individualisation noted above, however, this process of defamiliarisation again draws attention to the individual life lost by foregrounding the complexity and plurality of that life. Such defamiliarisation corresponds to Davis's position that, "[t]he responsibility of the

\footnotetext{
${ }^{6}$ See Esbenshade's essay for a fuller discussion of the cycles of renewal and forgetting of Eastern and Central European postwar national memory.

7 Note that the phrase "la fleur du temps qui passe", which is also the title of the first section of Immensités, is most probably drawn from a French cover version of a well-known freedom song by Pete Seeger. The French version, by Dalida in 1962, contains the line "Que sont devenues les fleurs/Du temps qui passe".
} 
witness is $[\ldots]$ to regard the other's pain as something alien, unfathomable, and as an outrage which should be stopped" (p. 30 in Davis 2011). Defamiliarisation is therefore one way in which Germain's Czech texts negotiate the tension between, on the one hand, an empathetic and corporeal need to respond to stories of the suffering other and, on the other hand, the "unfathomable" nature of such suffering.

In bringing these stories to our attention, then, Germain is participating in a process that Susan Sontag has described as the act of "[r]egarding the pain of others" (Sontag 2003). There has been much critical consensus that the ethical difficulties surrounding the narration of the stories of others revolve around the speaker's adoption of viewpoint or, more precisely, the positioning of the voice of the speaker in relation to the other, the one who is spoken about or "for". In her exploration of the morality and implications of "[r]egarding the pain of others", Sontag has exploded the concept of a unified "we", arguing that "[n]o "we" should be taken for granted when the subject is looking at other people's pain" (p. 6 in Sontag 2003). ${ }^{8}$ There is an inseparable divide between "they" whose suffering is observed and "I" or "we" who look on, as Sontag writes (in response to Jeff Wall's photomontage of an imagined scene from the War in Afghanistan, in which his reanimated dead and mutilated soldier victims appear to be talking companionably to one another, yet ignoring the viewer rather than "speaking" or appealing for sympathy or in protest):

Why should they seek our gaze? What would they have to say to us? "We" this "we" is everyone who has never experienced anything like what they went through - don't understand. We don't get it. We truly can't imagine what it was like. [...] Can't understand, can't imagine (p. 113 in Sontag 2003). ${ }^{9}$

The incomprehensible and unimaginable nature of the other's experience creates a bond or community to which Wall's photomontage draws attention, and Davis takes up Sontag's argument to further insist that "[t]he reader-the non-survivor-is not and cannot be part of the community" (p. 38 in Davis 2011). Like the photographer Wall, Germain is working from "outside" that community of sufferers whose pain she is picturing; like many of the viewers of Wall's image, the (French) reader of Germain's Czech works cannot be assumed to have experienced the traumas and difficulties represented within.

And yet, as both Sontag and Davis insist, this precondition of non-comprehension, of non-identification with the victim, does not and must not preclude the act of witnessing, since we are all humanly and morally bound "to pay attention, to reflect, to learn, to examine the rationalisation for mass suffering offered by established powers" (p. 104 in Sontag 2003). This thought intersects with Thomas Trezise's articulation of the possibility and indeed moral imperative of the existence of a community that acknowledges, upholds, and yet transcends the differences between

\footnotetext{
${ }^{8}$ Whilst Sontag's argument centres largely on the medium of war photography, her argument has already been widely extended to the discussion of literary texts and, in the light of Germain's understanding of literature as a form of Levinassian "regard" (discussed below) can be pertinently applied to Germain's fiction.

9 Sontag is referring to Jeff Wall's "Dead Troops Talk (A Vision After an Ambush of a Red Army Patrol near Moqor, Afghanistan, Winter 1986)", 1992.
} 
survivor and non-survivor, or sufferer and observer (Trezise 2002). For Trezise, the ethical responsibility lies with the reader, who is called on to become, through the act of reading, "a second person capable of understanding that knowledge itself is not the horizon of listening" (p. 886). In other words, the possibility of an ethical relation or community between the other, whose pain we regard, and the self is enabled by the very act of "regarding" (or "paying attention to") that suffering which we nonetheless accept we do not "know" and cannot share in. Germain as a writer is thus impelled to respond to the pain of others by creating a transgenerational and transnational textual "space of remembrance" (p. 10 in Hirsch 2001) in which we can acknowledge, if not comprehend, the pain of others. In her passage describing the stall-keeper's corporeal reaction to Auschwitz, in her naming of dispossessed and persecuted Czech writers such as Skácel, and in the call to "regard" the dying child, Sarah, the "understanding that knowledge is not the horizon of listening" is played out, and the only ethical response seems to be that of Germain's stall-keeper, to "tomber à genoux" [fall to one's knees].

\section{Germain's Adoption of a Position of Proximity to the Czech Narrative of Suffering}

I have already suggested that, although these texts are not "autobiographical" in nature, Germain nevertheless inscribes herself into the text as, for example, in the manner in which the stall-keeper's corporeal response to Auschwitz reflects her own response to Struthof. A closer look at the manner in which she represents her own presence in Czechoslovakia in terms of narrative voice serves to reinforce my argument. In her study of the narration of pain in La Pleurante, Isabelle Dotan considers the relative functions of the "je" [I] of the narrator and the "elle" [she] of the weeping figure who, she says, displaces the narrator as the subject of the text:

[1] e sujet manifesté devient un sujet effacé qui tente, en vain, de reprendre la maîtrise du texte. La Pleurante s'impose à elle et au fil du récit, le je n'est plus qu'un stylo, un médium qui se retire subjectivement du texte (p. 141 in Dotan and Michel 2006).

[The apparent subject is erased as subject and tries, in vain, to regain control of the text. The Weeping Woman imposes herself on the narrator and gradually the narrative I becomes no more than a pen, a medium which withdraws as a subject from the text.]

This point supports Dotan's argument that the third person "elle" of La Pleurante is the motivating force of the memories that surge up through the text, and therefore the instigator of the act of writing itself, in which process the writer becomes the "médium" between the images that had been consigned to memory and the recipient reader. This process of mediation is described by Germain herself in $L a$ Pleurante: "[l]e vent, le vent de l'encre qui souffle dans ses pas fait se courber, se balancer les mots, déracine des images qui demeuraient enfouies dans la mémoire à la limite de l'oubli" ([the wind, the wind of ink that is summoned up by her 
footsteps brings words to life, raises up images that had been buried deep in memory on the edge of forgetting] p. 18). However, whilst the narrative "je" is undeniably inspired and activated by the images of the past that are called up by the footsteps of the weeping woman, I propose that this first person narrator does not in fact "se retire[r] subjectivement du texte" [withdraw as a subject from the text] but rather remains present and inscribes herself in a variety of ways into the wider collective body of memory that is represented in this text.

One such means of self-inscription is the very choice of a first person narrator in La Pleurante, which we can assume to be significant if only because this is to date the first and only time that Germain has used this device in her fictions, which are otherwise exclusively narrated in the third person. Michel Butor discusses the difference between first and third person narratives, claiming that the former "représente l'auteur" ([represents the author] p. 67 in Butor 1964), which in the light of the unusual choice, for Germain, of first person narrative voice suggests that there is a significantly close association between the narrator and the author in $L a$ Pleurante. We should of course be wary of equating the two since, as Butor reminds us, "[1]e narrateur, dans le roman, n'est pas une première personne pure" [the narrator of a novel is not a pure first person], but rather a point of confluence between the worlds of the fiction, the author and the reader (p. 63 in Butor 1964). However, the Butoresque presence of the author within the narrative "je" of $L a$ Pleurante supports my position that Germain is inscribing herself through this work into the world of the text, that is, into the world of the figure of the weeping woman, who is inextricably associated with the world of the Czech nation. The author's presence in the textual world through this use of "je" corresponds, furthermore, to Germain's actual, physical presence in Prague at the time of writing. Rather than withdrawing from the text, the first person author/narrator figure is surely insisting on a place within the text, within the worlds that it represents and that the author herself has gradually become absorbed into, and so adopting a position of proximity to the Czech stories and memories that she is re-telling.

This notion is supported by the precise physical manifestation of the "je" who periodically reappears at different locations in Prague within the text, and most significantly in two passages referring to the narrator's father. The first of these occurs during the sixth apparition, when the figure of the weeping woman appears in the hillside district of Vinohrady. She is walking with a particularly pronounced limp ("[s]on grand corps plongeait profondément à gauche puis rebasculait vers la droite en un tangage régulier" [her large body pitched backwards and forwards, lurching heavily to the left and then back to the right] p. 54), which resonates with the painful image of the narrator's dying father that is now evoked: "un homme qui gisait alors dans un lit à mille kilomètres de là, le corps rompu par la maladie" ([a man lying in a bed a thousand kilometres away, his body broken by sickness] p. 55). It is significant here that the memory of the father appears to the narrator across the geographical divide that separates his home in "le quartier d'Auteuil, à Paris" [the Auteuil district of Paris] and the narrator's position in "la rue Chorvatská à Vinohrady" [Chorvatská street in the Vinohrady district] in Prague (pp. 56, 54); this bringing together of the two places on the page of the text again "bridges" the geographical distance between the two countries in a manner that reinforces 
Germain's vision of the possibility of a transnational encounter that might acknowledge without appropriating the suffering of the other.

The narrator returns to the memory of her father in the very last lines of the "Dernière apparition" [last apparition]. He has now died and takes his place alongside the other "ghosts" whose memory is summoned up by the weeping woman: "il y a, parmi cet immense peuple de défunts qui sommeille dans ses haillons, le visage et la voix de mon père" ([There, amongst the vast hordes of the dead who slumber in the folds of her tattered garments, is the face and the voice of my father] p. 108). This return to personal memory reasserts the presence of the author/narrator at the end of the text, as confirmed in the following lines taken from the end of the "Épilogue": "Il sera temps de consentir à la dépossession, à l'amour et à l'humilité, et de dire: "Me voici!"” ([There will be a time to submit to dispossession, to love, and to humility and to say, "Here I stand"] ${ }^{10}$ p. 128). This reassertion of narratorial/authorial presence takes place even as the weeping woman herself withdraws from Prague and from the text, since the epilogue opens with the words, "[e]lle a quitté la ville" ([she has left the city] p. 113), and closes by confirming that "[e]lle est sortie du livre [...] rôder ailleurs" ([she has left the book... to wander elsewhere] p. 127). Far from "withdrawing" from the text, then, the author/narrator (as I have defined the term in relation to Butor's usage) inscribes herself as a "witness by adoption" (Hartman 1996) into the narrative of Czech suffering. To better understand Germain's position as a foreigner placing herself in this proximity to Czech stories, we can turn to Kristeva's understanding of the biblical character of Ruth: "Ruth l'étrangère est là pour rappeler [...] que la révélation divine nécessite souvent un écart, l'acceuil de l'altérité radicale, la reconnaissance d'une étrangeté" ([Ruth the foreigner reminds us that... divine revelation often requires a distance, an embrace of radical alterity, a recognition of that which is foreign] p. 110 in Kristeva 1988). Like Ruth, who chose to remain far from her homeland, Germain (during the time of her stay in Czechoslovakia) occupies a place of "écart" [distance] from her own home in France which is emphasised by the presence of the French first person narrator in Prague. By insisting on her presence in Prague and within her story of Czechoslovakia, Germain is once again highlighting her encounter with "[une] altérité radicale" [radical alterity] and pointing to the enlightenment that can emerge from such an embrace of otherness, since her writing resonates with Kristeva's position that "la révélation divine nécessite souvent un écart" [divine revelation often requires a distance].

Her adopted proximity to Czech stories ("Me voici!" [Here I stand]) becomes an acceptance by Germain of the task of opening oneself up to the other and listening to their stories of pain, a task whose difficulty Frank has set out in the following terms: "One of the most difficult duties as human beings is to listen to the voices of those who suffer. [...] Listening is hard, but it is also a fundamental moral act" (p. 25 in Frank 1995). My analysis shows that, in line with Hirsch's statement that "postmemory need not be strictly an identity position" (p. 10 in Hirsch 2001),

\footnotetext{
10 The words "Me voici" appear to be a reference to the phrase "Here I stand" that is attributed to Martin Luther's speech at the Council of Worms. Although it is now widely contended that Luther did not speak these words, in view of Germain's engagement with Christian values my translation deploys this phrasing to retain the allusion, rather than using the more neutral "Here I am".
} 
Germain's work takes the stance that, even if we cannot claim to comprehend, we are nevertheless morally called to listen and to bear witness not only to stories of our own familial or social group, but also to stories emanating from the more distant other, the value of whose lives, both collectively and individually, weighs "un poids gigantesque" [a huge weight]. Germain does not "strictly" have a claim to a Czech identity position and yet her creation of a transnational testimony demonstrates one way in which we, like Ruth as understood by Kristeva, can embrace "radical alterity" with humility rather than "arrogance".

My analysis so far has established that Germain's work is preoccupied with a sense of both personal and European alienation or exile deriving particularly from the "atrocities" of the twentieth century, from the Holocaust to totalitarianism, a sense which plays out in tropes of the suffering body which are externalised in the response she is impelled to make to the pain of the (Czech) other. Although her writing foregrounds the incomprehensibility of suffering in the other, Germain nevertheless takes points of common experience (and particularly that of physical or emotional exile) as a starting place from which to build a "bridge" (Davis 2011) between herself and the other in a manner that conforms to Frank's concept of a "brotherhood of those who bear the mark of pain" (p. 35 in Frank 1995). Furthermore, Germain's detachment from her own country and the empathetic insight derived from her position as "une étrangère" [a foreigner] in Central Europe heightens her sense of the moral imperative of opening ourselves to alterity, of taking on the "difficult task" of listening to the stories of others, and of responding in a manner that, in Levinas's wording, "opens suffering to the ethical perspective of the interhuman" (p. 94 in Levinas 1998). It is through this placing of her own self in a position of proximity to the suffering other that her Czech writing avoids the "arrogance" of assuming authority over the other's story, and can be interpreted as a transgenerational and indeed transnational "witness by adoption".

\section{Writing out Solidarity with the Suffering Czech Body}

Building on this understanding of Germain's writing as a transnational witness to the condition of dispossession experienced by many in Central Europe particularly as a result of the events of the Second World War and the Holocaust, I now turn to an analysis of Germain's use of the body, and particularly of tropes of illness, to describe more specifically the collective and individual effects of the Communist era. These tropes include the presentation of the wounded, limping figure of the weeping woman; descriptions of the Czech nation as mute in La Pleurante and as blind in both Immensités and Éclats; the association in Immensités of Prokop and his dissident friends with illness; and Ludvík's symptoms of a figurative "nausée" [nausea] in Éclats. My examination of these features intersects both with Frank's descriptions of the illness narratives of patients suffering or recovering from physical disease, and with Sontag's exploration of the metaphorical applications of the names, attributes, and effects of illnesses across the ages. Whilst the Germainian figures I shall refer to as "wounded" or "ill" belong, in the vast majority of cases, only figuratively to what Sontag has famously described as the "kingdom of the 
sick" (p. 3 in Sontag 1983), many of Frank's observations of the phenomenon of physical illness can also be applied to widen our understanding of Germain's presentation of these characters as afflicted.

In dialogue with Goulet, Germain discusses the damage that may be experienced by those who do not have access to the stories of their familial past in the following terms:

Il en va de même avec les personnes auxquelles on cache certains secrets de famille, secrets trop honteux ou douloureux pour être dévoilés; elles ressentent un malaise, ont des intuitions, même si cela reste confus. Il y a toujours des fantômes embusqués dans les placards qui finissent par trahir ces secrets. On ne sait pas trop comment cela se passe, mais ça revient, ça suint des non-dits, de l'oubli (Germain, p. 240 in Goulet 2008).

The same is true for those from whom family secrets are hidden, secrets that are too shameful or painful to be revealed; such people experience a malaise, they have intuitions, however intangible these feelings may be. There is always a skeleton lying in wait in the closet to give away these secrets. We don't really understand how, but these things, the unspoken, the forgotten, come back to haunt us.]

The mark left by these "fantômes embusqués dans les placards" [skeletons lying in wait in the closet] may take the form, in Germain's work, of either psychological or bodily damage. Many of the protagonists of her early novels bear the wounds of the past visibly on their bodies in the form of scars or disfigurements, and we can interpret this bodily marking in the light of Germain's observation that her grandfather, veteran of the Second World War, bore the scars of that time on his body, a scarring which acts as a further link between Germain and the legacy of that era: "Mon grand-père a fait toute la guerre 14-18. Il en portait des traces dans le corps" ([My grandfather fought through the war of 1914-1918. He bore its marks on his body] p. 249 in Goulet 2006). This trend of bodily marking-out of suffering is continued in Germain's depiction of the figure of the weeping woman, whose body is marked by the sufferings of Prague.

The weeping woman is immediately presented in a detailed language of wounding: "elle boite fortement. Sa jambe gauche est beaucoup plus courte que la droite. Elle soulève ses pieds avec peine" ([she limped heavily. Her left leg was much shorter than her right. It was an effort to walk] p. 19 in Germain 1992). This physically damaged body becomes a meeting place of time whereby different moments of sorrow converge: "Son corps était un lieu de confluence d'innombrables souffles, larmes et chuchotements échappés d'autres corps" ([Her body housed countless sighs, tears, and murmurs that had escaped from other bodies] p. 33). Her body thus encompasses the memory not only of the Second World War and Holocaust in Central Europe, but also of the subsequent period of Communism:

Elle est née des pierres de Prague [...]. Elle est morte de mille morts au cours des guerres et des insurrections, des grandes épidémies et des pogroms. Elle a pris souvent la route de l'exil avec les bannis, la route des ténèbres avec les déportés (pp. 115-116). 
[She was born out of the very stones of Prague... She has died a thousand deaths during wars and insurrections, during epidemics and pogroms. She has trodden the paths of exile with the banished, the paths of shadows with the deported.]

The weeping woman, then, is a symbol not only of the suffering of the people of Prague during the war, but also, since "[e]lle a pris souvent la route de l'exil avec les bannis", of the more recent losses of the Communist era, which had ended in 1989 during Germain's stay in Prague and just before the publication of this text in 1992. The reference to exile in this passage again stakes out an explicit connection between the troubles of the Communist years and the wider theme of dispossession that underpins Germain's writing. This extension, in the form of the weeping woman, of the trope of corporeal marking (which Germain had used in previous works to embody the effects of the legacy of a war to which she feels "directement héritière" [a sense of direct inheritance], p. 2 in Glaiman 2005) to encompass the effects of Communism suggests that Germain is beginning to mark out her empathy for the damage caused by that period in Czech history.

What is particularly interesting about the cases not only of the weeping woman, but also of the sick protagonists who will be examined in more detail below, is that it is again the body that is used to tell the story of these totalitarian-era wounds and silencings in a way that corresponds to Frank's observation that (in the case of Judith, a sick woman with whom he corresponded), "[h]er story was not just about illness. The story was told through a wounded body. The stories that ill people tell come out of their bodies" (p. 2 in Frank 1995). This emphasis on the use of the body to create its own language of storytelling or witness recurs throughout Frank's account of the interviews and correspondence he held with a range of ill people. Frank uses this notion of a language of illness "coming out" of the body to introduce the concept of illness narratives as testimony, whereby "[p]eople who tell stories of illness are witnesses, turning illness into moral responsibility" (p. 137 in Frank 1995). If we accept Frank's claim, then we can interpret Germain's Czech texts (since each tells "stories of illness" through wounded or ill bodies) as a form of witness, whereby both writer and reader are called to assume "moral responsibility" to listen to the stories of pain, silencing, and dispossession that are narrated in these texts.

I propose, however, that there is a shift from the way in which La Pleurante embodies the pain of the twentieth century in its entirety in Central Europe through the trope of wounding, to a use of illness to more specifically map out Communist era losses through the body in the other three Czech texts. It is possible that this change takes place as a result of a gradual process of detachment from France (and Western preoccupations) of which Germain has spoken in interview, whereby she felt that "quelque chose de la France se détachait de moi et par contre mon imaginaire, à force de vivre à Prague, a fini par être marqué par Prague et la Bohême, par l'histoire de ce pays" ([some part of France detached itself from me, but at the same time my imagination, from living in Prague, has been marked by Prague and Bohemia, by this country's history] Germain, in Richter 2005). La Pleurante was the first Czech-based text to be published (in 1992) as a result of Germain's stay in Czechoslovakia, and I posit that the three subsequent texts, published progressively from 1993 to 1998, are more specifically marked by the 
totalitarian era that was still playing out during the time of her presence in the country. In these latter works, each protagonist is variously alienated or dispossessed by the strictures of the Communist regime, and their inner struggles are manifested in symptoms of bodily sickness; this pattern first becomes evident in Immensités, whose protagonist Prokop, like Ludvík in Éclats, embarks on an emotional quest for internal resolution of the troubled state of mind in which his country's oppressive environment has left him. Both Prokop and Ludvík are afflicted with symptoms of illness which, I shall argue, can be aligned with the sociopolitical context in which they are forced to live.

The shift from graphic images of wounding (in the early French novels and in $L a$ Pleurante) to tropes of illness constitutes a move in Germain's work from a largely transgenerational position of witnessing to the legacy of the Second World War, to a transnational form of "witness by adoption" in relation to the losses of the totalitarian era. This shift towards tropes of illness can be explored in terms of Germain's observations about the specific nature of Communist era experience. Building on her concept of the "malaise" that is felt by those who do not have access to the "fantômes embusqués dans les placards" [skeletons in the closet] of their family pasts, Germain goes on to describe more specifically her perception of this "malaise" in terms of politically oppressive contexts in which the past is officially manipulated or concealed from entire peoples or nations:

Quand on veut imposer l'oubli à un peuple, en éradiquant certains évènements de son passé, en falsifiant son histoire, en essayant de lui mentir, de lui voler une part de son héritage historique, on le fragilise, on le rend malade - et bien sûr plus facilement manipulable, ce qui est le but de la fraude (Germain, p. 240 in Goulet 2008).

[If you try to impose oblivion on the people of a nation by erasing certain events from their past, by falsifying their history, by attempting to lie to them or to steal part of their historical heritage, then you make them weak and sick and of course easier to manipulate, which is the aim of the fraud.]

Germain's description of the effects of the "fraud" perpetrated against the Czechs as a sickness ("on le rend malade"), helps us to understand the illness-related imagery in the Czech texts as part of her response to the Czech loss of their heritage. The use of illness to portray the theft of memory intersects with the association, examined above, between exile and sickness, since the Czech "illness", as portrayed in Germain's latter three Czech stories, is a result of the exile of a nation from the past and from memory by means of totalitarian "fraud".

\section{Muteness, Blindness and Nausea: Reading Germain's Czech Novels as Narratives of a National Illness}

Having aligned Germain's narration of stories of a Czech condition of figurative illness with Frank's understanding that stories of illness are told through the body, it is also possible to identify specific "symptoms" that Germain deploys to map out 
her perception of the effects of the "theft" of memory and identity during the totalitarian regime. The first of these is muteness, manifested not only by individual characters, but also by the figure of the weeping woman and indeed by the city of Prague itself, whose buildings are not only neglected and broken but also imbued with a human quality of sorrowful silence. Germain's "rues de Prague" [streets of Prague] are full of dilapidated buildings, such as "une maison désaffectée aux vitres cassées, à la façade décrépie et noircie" ([an abandoned house with broken windows and a decrepit, blackened façade] pp. 39-40 in Germain 1992), many of which are covered in scaffolding (p. 19) and shrouded in "la brume [...]. Les fumées [...], la poussière" ([fog, smoke, dust] p. 23). These images of brokenness and dilapidation specifically relate to the Communist era policy of erasing cultural memory by neglecting or even destroying historical buildings. (One example lies in the fate of the nineteenth century railway station of Těšnov in Prague, the anniversary of whose 1985 demolition by the Communist government was recently commemorated in March 2015; see, for example, Willoughby 2015). For Germain, the buildings of Prague are silent witnesses to the losses suffered, as we see in a passage describing one decrepit house in Prague's district of Malá Strana: "La maison condamnée émettait un ultime souffle, une plainte en sourdine" ([The condemned house drew its last breath, a mute cry] p. 40 in Germain 1992). This silence is carried over into Germain's portrait of the weeping woman herself. We have seen that she is the embodiment of Prague's history and of the pain of its inhabitants, whose tears can be heard within her body: "Car il semblait que quelque chose pleurât en elle, et non pas qu'elle même versât des larmes" ([For it was as if something was weeping inside her, and not that she herself was crying] p. 33). Other than this sound of tears that emanates from her body, the weeping woman, like the buildings of Prague, is silent, never uttering a word.

In Immensités, a similar metaphorical muteness emerges as a characteristic of those who are persecuted by the Communist regime. The novel opens with a description of Prokop and his fellow dissidents as "relégués dans la très poussiéreuse salle d'attente de l'Histoire" ([relegated to the very dusty waiting room of history] p. 20), a metaphor which frames Czech dissident victims of the regime as sick patients lacking hope of any imminent cure. Each and every one of these friends has been stripped of their former employment and relegated to some insignificant, menial position: the jazz saxophonist Viktor now tends central heating systems in the gloom of apartment basements (p. 26), ${ }^{11}$ whilst Prokop himself, a former teacher of literature, is now "relégué dans la marge" [relegated to the margins], reduced to sweeping the streets like "un paria", an image which in itself carries inescapable associations of leprous disease (pp. 16, 15). Radomír, "ancien documentariste chassé de la télévision" [a former news reporter who had been banned from the television], has been deprived of his public voice and must spend his days washing windows, "[à] défaut de décaper le regard de ses concitoyens par le biais de reportages d'une justesse acide" ([instead of enlightening his fellow

\footnotetext{
11 Note that jazz was an art form despised and banned by the regime because of its association with freedom movements. The repeated references to jazz in Immensités constitute an element of Germain's sympathy for Czech dissidence as a form of resistance to oppression.
} 
citizens by means of his sharply observed reporting] p. 24). The relegation of these former professional and creative individuals to these positions, and thus to the "waiting room of history", has variously removed their voice and agency in a way that aligns them with Frank's vision of the voicelessness of the sick whereby "[s]eriously ill people are wounded not just in body but in voice" (p. xii in Frank 1995). Although these individuals are not physically sick or wounded, the figurative removal of their voice reflects their powerlessness in a way that qualifies them for inclusion into the "kingdom of the sick" (p. 3 in Sontag 1983).

Germain's articulation of Czech stories in terms of illness intersects with Frank's insight that the recovery of voice entails return of agency and thus brings healing to the sick subject of the narrative, even if on psychological rather than physiological terms: "ill people [...] learn by hearing themselves tell their stories, absorbing other's reactions, and experiencing their stories being shared" (p. 1 in Frank 1995). If storytelling can be a restorative action in relation to the sick self, in the case of Germain's telling of the stories of an other "ill" subject (or nation) we need, however, to consider the question of voice more closely. In the narratives examined by Frank, it is critically important that the narrator is the patient, the victim of the illness, and not an external observer (such as the doctor or medical expert who, as Frank points out, was the voice speaking on behalf of the mute patient during what he terms the "modern" era of medicine). ${ }^{12}$ This is because Frank understands the telling of the illness story in what he refers to as our "postmodern" era as a means of reclaiming one's voice, a tool used by people needing to tell their own stories of "what illness has imposed on [them] and seeking to define for [themselves] a new place in the world" (p. 7). Germain's Czech stories are of course narrated in French, by a French writer, and, accordingly, to a predominantly French readership. In the light of Frank's insistence on the importance of telling "one's own" story, it could be assumed, despite the position of empathy that I have insisted that she occupies, that Germain's stories of Czech "illness" constitute a purely third-party narration of someone else's suffering, and as such should be aligned rather with the "modern" trend whereby the patient is displaced from their own story through its telling by another party (by the medical expert in the case of literal illness; in this case, by the author). However, the bodily nature of Germain's narration of the sufferings of Prague, corresponding as it does to Frank's understanding of the narration of illness through the body, confirms my interpretation of these texts as a form of "interhuman" witnessing (to return to Levinas's term) to a story into which, as I have shown, Germain inscribes herself through the bodily process of placing herself in a position of proximity in order to "listen" and respond to the suffering other.

Furthermore, Germain's voicing of these stories of the ill and muted other intersects with her mission to restore a voice or identity to the marginalised and forgotten. Accordingly, the weeping woman repeatedly ushers in the memory and names of individual inhabitants of Prague (and beyond) who have themselves been marginalised, rendered mute, and so forgotten, such as the Polish Jew Bruno Schulz,

\footnotetext{
12 For a discussion of what Frank terms "the modern experience of illness", see Frank (1995), pp. 5, 6; pp. 4-7 set the notion of the "modern" medicalisation of illness in the context of the 'pre-modern' illness experience, which was dominated by folk tradition, and of the "postmodern" experience, which Frank argues is characterised by a reclaiming of voice and agency, and thus responsibility, by the patient.
} 
"tué par une balle dans le dos, en plein jour" [shot in the back in broad daylight], whose writings have been lost to posterity and who represents countless others who have had "des voix tues [...], des mots perdus" or "[la] voix volée"([their voices silenced forever, their words lost, their voices stolen] pp. 42, 43 in Germain 1992). These silenced voices also include those of the authors of the texts cited in the epigraphs to each apparition of the weeping woman, such as the banned poet Skácel, referred to above, ${ }^{13}$ or Bedrich Bridel, the seventeenth-century Jesuit missionary who was persecuted because he continued to write in and promote the Czech language despite the repressive Germanisation of the Hapsburg Empire. The weeping woman thus appeals, albeit voicelessly, to the narrator (and consequently to the reader) for recognition on behalf of these variously silenced individuals and groups: "Elle recèle tant de noms dans les replis de sa robe qu'ils pourraient, tous ces noms, former un peuple. Comme les noms gravés sur les murs des mémoriaux" ([There are so many names hidden in the folds of her dress that they could make up an entire nation. They are like the names engraved on memorial walls] p. 59). Once again, this emphasis on naming recalls Paver's descriptions of the use of necrology in memorials to "restor[e] individuality" to those who were rendered anonymous (p. 258 in Paver 2010). In the light of the lack of memorial to the losses of the Communist era, the body of Germain's weeping woman-and, by implication, the body of the text through which she walks-becomes a living monument to those lost names, some of which are brought back to our attention in the course of the apparitions and in the epigraphs, historical anecdotes, and intertextual references of this text. It is by opening up a transnational textual space of memorial and discussion of muted histories that works such as Germain's constitute an ethical response to the "interhuman" that is best understood in terms of Frank's stance that,

[a]n ethic of solidarity and commitment is expressed when the storyteller offers his voice to others, not to speak for them, but to speak with them as a fellow-sufferer who, for whatever reasons of talent or opportunity, has a chance to speak while others do not (p. 132 in Frank 1995).

Despite differences of familial, national and historical identity, Germain's portrait of the Czech exile from "une part de son héritage historique" [part of their heritage] externalises her participation as a "fellow-sufferer" and thus avoids the danger of appropriation; the Czech texts are the manifestation of her moral "solidarity and commitment" to the suffering other with whom she, like Ruth, has come into proximity and to whom she offers her "voice" in order "not to speak for them, but to speak with them".

Not only muteness but also blindness affects the Czechs both individually and collectively in Germain's representation. I have shown above that, like his dissident companions in Immensités, the former journalist Radomír has been politically punished by his removal from his position and relegation to the job of washing windows. Like his dissidence, however, this is a thankless task since "les vitres citadines se réencrassent presque aussitôt" ([the city's windows become dirty again

\footnotetext{
13 It is worth noting that in 2006 a plaque was placed in Svobodová náměstí ('Freedom Square') in Brno, citing a poem by Skácel, a sign of the very recent revival of some of these hitherto suppressed voices.
} 
almost straight away] p. 24 in Germain 1993a); the perpetually dirty windows are indicative of the Czech nation's inability or unwillingness to "see" the reality of their situation. This portrait of the nation's blindness is carried through into a key scene in Éclats which finally cements the disillusioned protagonist Ludvík's decision to flee the political situation in his totalitarian country. The scene is set at a typically Czech open-air country dance, complete with an array of symbols of traditional Czech folk identity including "bière et saucisses" [beer and sausages] and waltz music (p. 26 in Germain 1991); this setting reflects late twentieth-century Czech national pride in their folk heritage and culture of country balls. It is in the midst of this representation of his country that Ludvík sees a couple waltzing wildly, apparent paragons of Czechness in their participation in this archetypal Czech scene. To his shock, however, Ludvík then realises that the couple are blind, and so their sightless whirling translates itself into a symptom of his nation's desperate, short-sighted bid to ignore the disease of Communism that is infecting their country:

ce couple de patauds qui venait de guincher sans rien voir alentour, de se dandiner dans une nuit toute poissée de bière et de glue musicante [...], ce couple somnambule lui était apparu comme l'incarnation même du mal dont souffrait son pays, - une asthénie du goût et de l'esprit, une anémie du cœur, une cécité de l'âme (p. 27).

[This ungainly pair who had been dancing blindly on, waltzing about in a night that was oozing with beer and thick with music... this pair of sleepwalkers had seemed to him to be the very incarnation of the disease that had afflicted his country, - a debility of the senses and the intellect, an anaemia of the heart, a blindness of the soul.]

The medical language of disease and symptoms in this passage constitutes one of Germain's most direct and impassioned invectives against the legacy of politically induced oppression and damage to which she became witness during her stay in Prague. As such, the passage intersects with Sontag's observation that "[i]llnesses have always been used as metaphors to enliven charges that a society was corrupt or unjust" (p. 73 in Sontag 1983). What is less easy to explain, however, is that it is the couple themselves (rather than the political system or government) who appear to be the subjects of the metaphor at this point in Éclats, and this invokes the question of whether Germain, despite the empathy for which I have argued, is nevertheless to some extent attaching blame to the Czech nation that the blind pair represents.

Sontag's discussion of perceptions of illness over the ages shows that notions of culpability have been attached as we would expect to the illness itself, as "killer", but also indeed to the patient: "[w]idely believed psychological theories of disease assign to the luckless ill the ultimate responsibility both for falling ill and for getting well" (p. 59 in Sontag 1983). The question therefore arises as to whether, in the image of blindness, Germain is similarly judging the responsibility of the Czech nation, and, if so, what this means in the light of her status as an external, non-Czech observer. The key to answering the first part of this question lies in the particular nature of the imagery used by Germain to describe the afflicted nation. Sontag makes a distinction between, on the one hand, the "relatively contentless" nature of 
traditional figures of illness (whereby "no disease has its own distinctive logic", p. 73) used to metaphorise the "body politic" and, on the other hand, the often "virulent, preposterous, demagogic" language that invoked specific "[m]aster illnesses like TB and cancer" to polemicize social disorder in the modern age (pp. $73,75)$. This distinction is useful in illuminating the nature and purpose of Germain's engagement with the diseased "body politic" of the Czech nation. Germain refrains in the passage cited above from naming a specific "master illness", to borrow Sontag's term, which aligns her imagery rather with the type of language that Sontag identifies in pre-modern illness discourse, which is used to "express concern for social order" or "complain of some general aberration of public calamity" rather than to identify or blame a specific cause (pp. 73, 74). The language used by Germain in the passage cited here (and indeed throughout her four Czech texts) is instead almost exclusively symptomatic: the nation is "aveugle", "somnambule", weakened by "anémie" and "asthénie" [blind, sleepwalking, anaemic, asthenic]. This is important because it implies that the body of the nation is the suffering patient (which is confirmed by the metaphor in Immensités of Prokop and his friends residing in the "dusty waiting room of history"), rather than the root of the disease itself.

However, whilst Germain's treatment of the Czech nation as "sick patient" is, as I have argued, largely empathetic, we cannot ignore the fact that Prokop is described as a "paria"; that the Czechs are apparently unwilling to figuratively "clean their windows" and in so doing take responsibility for regaining their lost sight; or that the image of the blind pair is couched in somewhat unattractive terms as "ce couple de patauds" [this ungainly pair]. An answer to this apparent tension between empathy and blame lies partly in Germain's comment (cited above) about the destructive, debilitating effects on collective identity of the "malaise" of totalitarianism (Germain, p. 240 in Goulet 2008). An important, if difficult, part of Germain's insight into the trauma of totalitarian regimes is this understanding that the citizens of such regimes are made vulnerable to subversive pressures, and as such may be "manipulable". Additionally, in the story of the stall-keeper, to which I have referred above, Germain points out that the figurative Czech "blindness" is not just a national trait but is in fact a more widespread human attribute:

Il nous est facile de condamner tous ces crimes anciennement commis, de dénoncer le double silence, vertical et horizontal, qui a laissé le champ libre aux bourreaux et porté à l'extrême la souffrance des victimes abandonnées de toutes parts; il est beaucoup plus délicat de nous contenter d'une impuissante déploration face aux innombrables crimes en train d'être commis (pp. 73, 74 in Germain 1991).

[It is easy to condemn all those crimes committed long ago, to denounce the double silence - vertical and horizontal - that gave free reign to the persecutors and that was complicit in the extreme suffering of victims who had been abandoned on all sides; it is far less easy to justify simply wringing our hands at the countless crimes that are still being committed today]. 
In this passage, relating to the Holocaust, Germain draws attention to the phenomenon of disbelief, which could be described as a form of blindness, that caused many to turn their eyes away from the realities and suffering being perpetrated; she points out, moreover, that we continue to blind ourselves to countless crimes today. In the light of this more widespread refusal to take ethical responsibility for the suffering of others (including suffering caused by oppressive regimes which of course continue to this day), the Czech inability to "see" is easier to excuse, since Germain is also at pains to portray the contaminating political "fraud" that has caused their blindness. In this way, despite a certain occasional ambiguity in relation to the Czech inability to assume responsibility for their own "sick" condition, Germain nevertheless maintains an empathetic position and, moreover, draws our eyes towards ourselves to contemplate our potential complicity or blindness rather than directing us to blame the (Czech) other.

If it is the case that, for Germain, the nation (both collectively and individually) is suffering from a metaphorical muteness and blindness, then the cause of the "illness" underlying these symptoms also merits further attention. In the following passage of analysis, I focus on Germain's choice to set the scene describing the blind couple in a typical Czech spa town. By their very nature, spas traditionally represent the restoration of both physical and mental health, and accordingly their appearance as a backdrop to the scene analysed above merits attention in the context of my discussion of the dichotomy of sickness and health in Germain's work. Some background information about the history of the spa in Central Europe is required here in order to ground my argument that the spa pictured by Germain is not, as we might expect, a symbol of the restoration of health, but rather a metaphor for the contagious corruption of the Communist regime, since it is in this setting that Ludvík becomes "nauseated" at the sight of the blind dancers and fears being infected by the sickness that was afflicting his country, to the extent that he goes into exile in Paris.

The lands of Central Europe are rich in mineral spa waters; those on Bohemian territory were promoted by Czech sovereigns as early as the Middle Ages and became internationally popular spa resorts by the beginning of the nineteenth century, reaching the heights of success during the Art Nouveau period which preceded the prosperous and culturally "golden" years of the newly independent First Czechoslovak Republic of 1918-1938. The spas were also supported by the Czechoslovak Communist Party's public health policies in the mid-twentieth century although, like many of the buildings of Prague, many of them fell into a state of dilapidation as a result of the regime's poor economic management. It is indicative of Germain's broad understanding of Czech culture and history that her passage depicting a spa town captures the nation's sense of fall from the early twentieth-century "temps glorieux des curistes" ([glorious years of spa-going] p. 25 in Germain 1991), a fall which is manifest in the trappings of the spa, now suffering from the general economic neglect that pervaded the Communist Bloc: "De cette époque souveraine il ne restait plus désormais qu'un décor assez lépreux" ([Nothing remained of this golden era but some peeling paint] p. 25). The choice of the adjective "lépreux" [leprous] to describe the decaying state of the decor creates an association between the Communist policies that are evident in the dilapidation of 
this setting, and leprosy, which, as Sontag points out, is an illness that historically carries particularly negative connotations: "the leper was a social text in which corruption was made visible; an exemplum, an emblem of decay" (p. 59 in Sontag 1983). In Éclats, then, the "lépreux" spa setting becomes one such "exemplum" of the "decay" resulting from political corruption, and as such symbolises the totalitarian disease that is contaminating the nation, metaphorically infecting individuals (such as the blind dancers) with symptoms of "asthénie [...], anémie [...], cécité" [asthenia, anaemia, blindness].

Furthermore, the spa setting is illuminating with regards to Germain's understanding of the difference between physical and emotional national wellbeing in the Communist context. In her work on the use of the body as a trope in literatures in German emerging from the former Eastern Bloc, Lyn Marven has described how totalitarian regimes maintained social control by implementing an appropriation of the individual body in such a way that it effectively becomes the property of the state (pp. 17-27 in Marven 2005). She lists methods used to perpetrate such an appropriation (including interrogation and torture; medical interventions such as abortion laws; and the use of collective sport) so that the "individual body became a sign of the nation" (p. 18). We could note that the idea of the body as a "sign of the nation" intersects with Germain's treatment of the limping and mute Pleurante as a "sign" of national brokenness, or of the blindness of the dancers as a "sign" of the passivity of some in the face of the politically induced national "sickness". To Marven's list of methods used by the state to subjugate the national "body" in these ways, we could add the vigorous political promotion of spa visits as a means of creating an illusion of physical "national health" that served to detract from the pursuit of individual emotional wellbeing. Germain shows her awareness of this disparity between the promotion of physical health and the absence of emotional health in the passage under analysis here, since the spa is filled with patients who, whilst presumably being treated for their physical ailments, are "dénués de joie, aux yeux inexpressifs, embués de somnolence [...] le cœur ne parvenait pas à battre, à flamboyer, à rire" ([devoid of joy, their vacant eyes blurry with lethargy... their hearts could not beat, could not blaze with passion or laughter] p. 26 in Germain 1991). The spa, then, is intimately linked to the corrupt power mechanisms of the regime and is a symbol of the ensuing perversion of national "health". As such, the spa as Germain portrays it becomes a subversion of a quarantine enclosure, a site of infection rather than protection: "La médiocratie au pouvoir avait inoculé cette maladie aux gens en prenant soin de les claquemurer dans l'étau des frontières afin d'en contaminer le plus grand nombre possible" ([the ruling mediocracy had injected people with this disease and cooped them up inside closed borders in order to spread the infection to as many as possible] p. 27). In Germain's metaphor, the spa becomes a microcosm of the system of "infection" at play in this totalitarian country that is cut off from the rest of Europe by the political closing of borders and lines of communication.

The ultimate symptom of the national sickness as it is portrayed here by Germain appears to be a state of passive or even complacent acceptance of the condition, epitomised in the final reference to the blind dancers: "Ce couple était le parangon du citoyen modèle,- - infirme de liberté, repu de leurres et de mensonges, et satisfait 
de l'être" ([This couple was the paragon of the model citizen,- - crippled by the lack of freedom, satiated with delusions and lies, and content with this fate] p. 27). We have seen that the already disillusioned Ludvík's perception, during his visit to the spa, of this sickness of his nation provokes in turn "une nausée" (p. 27) in Ludvík himself, a condition which brings him to the decision to flee his homeland in an attempt to escape contagion: “c'était par un souci d'hygiène mentale que Ludvík avait décidé un jour d'émigrer" ([it was out of concern for his emotional health that Ludvík decided one day to leave the country] p. 24). Thus far, we might deduce that the disease inflicting both the nation and Ludvík is politically induced, related to the concrete geopolitical context of Communist Czechoslovakia, and this would also follow from my reading above of Germain's use of the spa as a metaphor for the corruption of the regime. If we were to accept such a reading of Germain's work as purely politically motivated, then she would appear to be embarking on a mission to create a utopian textual vision of a society cured of political (and perhaps specifically totalitarian) disease. We might therefore expect that the figurative illness from which characters such as the blind couple or Prokop and his dissident friends are variously suffering, and which fills Ludvík with "nausée", would be "cured" by the advent of the Velvet Revolution which put an end to Communist rule in Czechoslovakia. If Germain were indeed interested purely in envisaging a political "cure", then we would accordingly expect to find a condition of collective as well as individual "health" prevailing by the end of Éclats as the text moves chronologically beyond the Velvet Revolution.

However, if we trace the projection of the disease as it is manifested in Ludvík, it becomes clear that this is not the case. On his return from exile in France after the Velvet Revolution, Ludvík observes with disquietude the "peau neuve" ([new skin] p. 29) now assumed by his increasingly Americanised country, and finds that he is still gripped by "une nausée plus grave encore que celle qui lui avait fait fuir autrefois son pays" ([a worse sense of nausea than that which had previously made him flee his country] p. 27). Although the country's sickness is undeniably associated with its oppression under Communism in ways that I have demonstrated to correspond to Sontag's understanding of the historical use of illness as a metaphor for "corrupt or unjust" societies (p. 73 in Sontag 1983), it now becomes clear that Ludvík's "maladie" transcends the purely political context of Communism. In order to reach a better understanding of the perpetuation of this malady in Ludvík, we can compare the "nouveau tempo" ([new tempo] p. 29) that he observes in post-revolutionary Prague to a key passage in Immensités describing the vertiginous yet ultimately disappointing changes brought about by the Velvet Revolution as experienced by Prokop, for whom "Prague était comme ces grands sabliers décoratifs emplis d'infimes grains minéraux de diverses couleurs; quand on les renverse tous les grains s'envolent [...]; on repose le sablier sur l'étagère et la vie continue" ([Prague had become like one of those large decorative hourglasses that are filled with tiny particles of many-coloured sand; when you turn it upside down the grains stream out... when you put it back on the shelf, life goes on] p. 117 in Germain 1993a). In short, the Velvet Revolution has failed to bring the sociopolitical healing or renewal hoped for by both Ludvík and Prokop. Although the new political state of affairs brings circumstantial improvements to some who, like 
the dissident Viktor who returns to playing his saxophone in a jazz band, are able to resume their chosen pathways in life, others (including Prokop and Ludvík) are disappointed or so unable to readjust to the new socio-economic realities that suicide (as in the extreme case of Prokop's friend Aloïs) seems the only solution, as Marie-Hélène Boblet has noted in her discussion of the ethical and political implications of Germain's work (p. 59 in Boblet 2008). Although I have shown that Germain is portraying an ailing society that has clearly been infected by a politically imposed "radical, horrible illness", political revolution in itself is nevertheless clearly not the cure proffered by these novels.

\section{A Levinassian Encounter with the Other}

On his return to Prague after the Velvet Revolution, Ludvík continues to suffer from a nausea deriving from a sense of alienation not only from his physical surroundings, but also from both himself and other people, to the extent that "les gens ne lui étaient supportables qu'à doses homéopathiques" ([he could only tolerate people in tiny homeopathic doses] p. 30 in Germain 1991). By the end of Éclats (which is chronologically the last published of the three novels set in Czechoslovakia, and so perhaps the "destination" of Germain's Czech fictional journey), Ludvík has, however, reached a state in which he feels "la joie pure de se savoir en vie, et en paix souveraine. Et il riait, riait" ([the pure joy of knowing himself to be alive and in a state of great peace. And he laughed and laughed] p. 185). I will therefore now examine Ludvík's progress from his condition of nausea to a state of joyful health. This progress is textually framed as a journey out into the Czech mountains, in the course of which a number of encounters are played out which, I shall argue, allow Ludvík to work through his disillusionment with and separation from the world. Levinas's philosophy of the relationship between self and other, and more particularly his understanding of the role of the "rencontre" [encounter], underpins my examination of Ludvík's metaphorical healing.

In terms of my analysis of Germain's Czech texts, the importance of Levinas's thinking about the relationship between self and other revolves around his departure from the tenet of traditional Western philosophy whereby the self was believed to be privileged over the other, a position that has often been used to both explain and justify the tendency of the self towards the suppression and incorporation of the other. Kristeva also gives an account of this trend in Western thought and ethics, summarising that even in societies most open to welcoming and hosting "l'étranger" [the foreigner], there is a requirement for that other to assimilate to the norm (see p. 10 in Kristeva 1988). Levinas's philosophy responds to this historical inclination towards the incorporation of the other by insisting, in a paraphrasing by Davis in his introduction to the philosophy of Levinas, that "the Other lies absolutely beyond my comprehension and should be preserved in all its irreducible strangeness" (p. 3 in Davis 1996). This "irreducible strangeness" of the other, moreover, corresponds to Kristevan thought that "l'autre est tout simplement... autre" ([the other is quite simply... other] p. 167 in Kristeva 1988), and also resonates in Sontag's and Davis's positions regarding the fundamental separateness 
of the observing, narrating "I" and the suffering subject. For Germain, the act of "regarding the pain of others" (Sontag 2003) furthermore requires us to accept and embrace the Levinassian "irreducible difference" of the other since, as Ludvík's former lover Katia tells him, "[i]l est bon que les gens nous paraissent un peu bizarres, c'est le signe que nous avons posé sur eux notre regard [...] et que nous avons noté en eux quelque chose de différent" ([it is right that people seem a little strange to us, it's a sign that we have truly looked at them... and that we have seen something different in them] p. 127 in Germain 1991). As I have already argued, one way in which Germain's work respects this "irreducible difference" is by insisting on the impossibility of fully understanding the painful experience of the other, as demonstrated in my analysis of the reactions of the stall-keeper to Auschwitz.

Despite this difference, however, the self may nevertheless meet the other by means of a Levinassian "face à face" in which, ideally, neither self nor other dominates or is assimilated and thereby reduced; as Davis explains, "[i]f the Other becomes an object of knowledge or experience ( $m y$ knowledge, my experience), then immediately its alterity has been overwhelmed" (p. 45 in Davis 1996). Rather, through the encounter with the other some aspect of the self may be revealed to itself, an idea which intersects with Kristeva's conception of the encounter as "le croisement de deux altérités" [the meeting of two alterities], whereby the meeting with "l'étranger" opens the individual to new understandings of themselves (p. 21 in Kristeva 1988). This reminds us again of the story of Ruth, who understood that it is through "l'acceuil de l'altérité radicale" [the embrace of radical alterity] that we can accede to "la révélation divine" ([divine revelation] p. 110 in Kristeva 1988). Germain clearly subscribes to the idea of the encounter between the "deux altérités' of self and other as an enriching and enlightening possibility, as we can see in the words of a lecture she gave on the "traces et réverbérations" of the work of Levinas in her own writing. Referring to Levinas's description of the "face à face", Germain insists that "[d]'une telle rencontre [...], on ne peut pas sortir intacte" ([from such an encounter [...] one cannot emerge unchanged], 16.20 min in Germain 2006). The "rencontre", as envisaged and textually enacted by Germain, not only leads us to "pay attention" (to use Sontag's terms) to the presence and existence of the other in "our" world, but also challenges us to reflect anew upon our self and our place in the world. Rather than a process of incorporation or reduction of the other, then, we have a process of change taking place within the self, which cannot "sortir intacte" [emerge unchanged]. Despite Ludvík's initial aversion to other people, this transformative encounter becomes the heart of his quest for meaning in Éclats, where it is summarised by Katia in a close echo of Germain's own words in the passage cited above: “On ne devrait jamais sortir indemne d'une rencontre, quelle qu'elle soit, ou du moins sortir inchangé; fût-ce d'un atome, on devrait chaque fois se trouver altéré" ([We should never emerge untouched from an encounter of any kind, or at least not unchanged; we should always find ourself altered, if only by a single atom] p. 127 in Germain 1991, my italics). It is this process of gradual change that Ludvík must undergo as he progresses, through a series of often challenging but enlightening encounters, towards a new space, that of "la joie pure de se savoir en 
vie" [the pure joy of knowing himself to be alive], and so away from his condition of nausea.

The transformative result of the encounter, according to an ancient Hassidic legend recounted by Katia later in the passage cited above, is the birth of "une nouvelle lueur, qui se nomme ange" ([a new gleam of light, which goes by the name of angel] p. 127, my italics), and this citation points us to the fact that the encounter entails a process that can perhaps best be described in terms of Germain's work as a process of enlightenment. Sabine Badré has explored this notion, pointing out that Ludvík's progression towards the resolution of his inner turmoil through a series of encounters with others is characterised by his movement from a place of darkness to one of light (Badré 2003). Goulet has described this movement in similar terms:

toutes les histoires de ses romans progressent de rencontres en rencontres, événements qui se révèlent généralement épreuves, ouvertures, occasions d'une initiation ou d'une révélation de soi par l'autre, de soi avec l'autre. Et les héros successifs s'avancent dans ce qui constitue leur quête vers l'espérance d'une issue, vers une lumière (Goulet, p. 15 in Dotan and Michel 2006).

[All of the stories in her novels move from encounter to encounter, - these are events which generally turn out to be tests, openings, moments of initiation or of the revelation of the self through the other, of the self with the other. And one after the other the protagonists go forwards on their quest towards a hopeful outcome, towards a light.]

The encounter with the other, then, is a point of light or "révélation" in the existential darkness of the world shared by Germain (after her childhood visit to Struthof) and her variously dispossessed, marginalised, and silenced protagonists. For Ludvík, the movement towards light is summarised in these words, found towards the end of the novel and after he has undertaken his journey into the mountains with its series of encounters: "il débarquait en pleine nuit dans le matin du monde" [in the middle of the night he arrived at the dawn of the world]; the dawning of light is explicitly associated with the encounters with others that he has just experienced (p. 181 in Germain 1991).

Germain's emphasis on light and on the encounter between self and other as a process of enlightenment intersects with Sontag's understanding of the process of "regarding" the pain of the other, since the very act of looking requires a source of light, and reminds us that for Sontag, as for Levinas, one outcome of the enlightening act of "encountering" or "regarding" is a transformation of "useless suffering" in the other into "meaningful suffering" in the observing self. For Levinas, "[t]he interhuman, properly speaking, lies in a non-indifference of one to another, in a responsibility of one for another", and this responsibility emerges out of the human encounter, from which we have seen that the self should not emerge unchanged (p. 100 in Levinas 1998). Levinas's understanding of the responsible "interhuman" relationship has been rationalised by Frank in bodily terms when he speaks of the "dyadic relation" between bodies that emerges from our condition of "shared corporeality": "[t]he dyadic relation is the recognition that even though the 
other is a body outside of mine [...], this other has to do with me, as I with it" (p. 35 in Frank 1995). This translation of responsibility towards the other into bodily language helps us to better understand Germain's response to the Czech other with whom she, like that other "étrangère", Ruth, came into physical community, and to whose suffering she expresses her response in the corporeal terms highlighted by my analysis in this study.

Germain expresses this responsibility towards the other, who "has to do with $m e "$, as an imperative to combat the "indifférence universelle" ([universal indifference] p. 69 in Germain 1992) towards the (suffering) other, an indifference that she identifies as one reason why evil and hardship (framed in these texts in images of wounding and sickness) are allowed to continue. The suffering other, she notes in La Pleurante, becomes invisible to us: "Ceux qui ont froid [...] Ceux qui ont faim [...] Nul ne les voit, ils sont si légers, transparents [...] Et si par mésaventure nous les apercevons, nous détournons vite les yeux" ([Those who are cold... Those who are hungry... They are seen by no one, they are so insubstantial, so transparent... And if by some ill chance we do notice them, we quickly turn our eyes away] p. 88). In this passage, Germain is referring to the impoverished of Prague, of Central Europe, of the world, and yet in her critique we can also recognise Western responses to the "invisibility" (Hawkesworth 2001) of the Eastern Bloc that resulted from the totalitarian closure of its borders. It is through opening ourselves to the non-assimilative encounter with the other that we can move beyond our introverted "indifférence" towards the other, and this recognition of alterity is central to the journey from "sickness" to "health". Having emphasised the transformative potential of the encounter, in the passage cited above from her lecture on the influence of Levinas, Germain extends the light metaphor to question why it is that, most of the time, we "reste aveugle" [remain blind] to the enlightenment of the encounter with the other (16.56 min in Germain 2006). The answer, her writing tells us, lies in Katia's reminder to Ludvík that we must "rouvr[ir] enfin les yeux sur les autres" ([open our eyes at last to others] p. 126 in Germain 1991), corresponding to Sontag's belief (cited above) that we are morally bound "to pay attention, to reflect, to learn". If the encounter with the other engenders a moral responsibility to open our eyes and respond, then Germain's writing of Czech stories is her response to that call and a means of drawing attention to the invisible, disregarded (Czech) other.

\section{A Journey from Sickness to Health: Reading the Czech Texts as "Quest Narratives"}

I have argued that, as well as using structures and tropes which revolve around the notion of a productive encounter with the other, these texts can themselves be interpreted as the site of an ethical encounter with the (Czech) other and a means of returning an identity and a voice to the marginalised and silenced. It is, however, important to note that the process of opening oneself up to the other, and to the change that may proceed from that encounter, may also be a process of pain or conflict. In this concluding section, I examine this process as a journey from 
sickness to health in terms of Frank's categories of illness narratives. Frank recognises three primary types of narrative (pp. 115-136 in Frank 1995): the chaos narrative foregrounds the disease and "imagines life never getting better"; the restitution narrative focuses on the cure and the expected outcome of return to health; and whilst quest narratives also move forwards towards a new state, unlike restitutions they do not ignore the suffering that is involved in both illness and the journey towards health: Frank claims that "[q]uest stories meet suffering head on; they accept illness and seek to use it" (p. 115). I propose that Ludvík's journey can be likened to the "quest narrative" since it allows him to confront the emotional dispossession that was engendered by the oppressive regime, and brings him to "un espace autre" (p. 181 in Germain 1991) in which he recognises his interconnectedness with the world.

Having fled from the "nouveau tempo" of post-revolutionary Prague, Ludvík immerses himself in the isolated peace and silence of the countryside. However, the transmutation of the mountain landscape of his retreat into "un désert" (p. 82), a place of wandering and trial, emphasises the fact that this period will also be beset with difficulty for Ludvík. This difficulty arises from his unwillingness to re-engage with the world so that, from his series of encounters with a range of characters, each of whom impels him to reflect uncomfortably upon himself, he initially emerges with a sense of unease equal to that which made him flee the city: "[un] malaise provoqué par ces rencontres importunes d'individus qui paraissaient chaque fois surgir de nulle part pour lui lancer des reproches, des moqueries ou de confus et pénibles sousentendus" ([a malaise provoked by so many unwelcome encounters with individuals who always seemed to appear out of nowhere to attack him with reproaches, taunts, or vague and hurtful inuendos] p. 104). Gradually, and against his will, the encounters begin to transform Ludvík so that "il sentait [...] se dissoudre le nœud de dégoût, de lassitude, qui enserrait son cœur" [he felt... a loosening of the knot of disgust, of lassitude that had tightened around his heart]; eventually, even, Ludvík is infected with a desire to reintegrate with the world: "[i]l éprouvait le besoin de reprendre contact avec les gens, de discuter avec eux" ([he felt the need to renew contact with people, to communicate with them] pp. 105, 106, 113).

In his essay on exile, Edward Said draws attention to the words of the twelfthcentury monk Hugo St. Victor: "The man who finds his homeland sweet is still a tender beginner; he to whom every soil is as his native one is already strong; but he is perfect to whom the entire world is as a foreign land" (p. 185 in Said 2001). Said's response to this passage can help to elucidate the process of change that I have traced in Ludvík. Whilst St. Victor draws attention to the necessity of detaching oneself from one's earthly home in order to reach a place of spiritual enlightenment ("he is perfect to whom the entire world is as a foreign land"), Said emphasises the process by which this "perfection" is reached: "the "strong" or "perfect" man achieves independence and detachment by working through attachments, not by rejecting them" (p. 185 in Said 2001). Whilst Ludvík's understanding at the very end of the novel that "peu importait désormais le lieu où il se trouvait, la ville où il habitait" ([from now on it would little matter where he found himself, where he lived] p. 181 in Germain 1991) echoes St. Victor's belief that "virtue" proceeds from detachment from the geographical home, we should 
further note that this position is reached only by "working through" (rather than "rejecting") that series of encounters in the mountains and indeed the "attachments" of his life. This "working through" can also be interpreted in the light of Frank's claim that "[t]he quest narrative tells self-consciously of being transformed; undergoing transformation is a significant dimension of the storyteller's responsibility" (p. 118 in Frank 1995). The "transformation" is, furthermore, envisaged by Frank as an "initiation through agony to atonement" and as a "road of trials", descriptions which resonate with Ludvík's struggle in the "désert" of the Czech mountain landscape to come to terms with the need to reintegrate himself into the world (pp. 119, 118 in Frank 1995). ${ }^{14}$

I propose that, in undertaking this quest to "return" to the world, Ludvík becomes a "sign of the nation" (to recall Marven's phrase) not only in that his "nausée" initially appears to be prompted by the political disease and corruption to which he is exposed, but also in the course taken by his voyage towards (figurative) "health". To understand this notion, we can return to Keller's and Hawkesworth's observations of the isolation experienced by Eastern Bloc nations. Germain has shown that she is aware of the pain and indeed danger inherent in this situation of isolation from the "other", as we saw in my analysis of her depiction of the spa as a subversion of a "quarantine" zone, a microcosm for the "unhealthy" enclosure of the nation behind the Iron Curtain. To recover a state of health, the nation must come out of quarantine, which entails a renewal of contact with the wider world, just as Ludvík must renew contact with other people. This transition is nonetheless a difficult process, and Germain acknowledges this in Ludvík's initial, troubled response to the "unwelcome" approaches of others. The individual and national voyage from sickness to health becomes a journey not from one political regime to another, but rather from a state of dispossession to a condition of internal freedom through the recognition that "perfection" (as envisaged by Said) lies for Germain in the Levinassian encounter.

I have shown in this study that Germain's Czech stories can be interpreted as an ethical response to the journeying of a nation into the "kingdom of the sick", a response that has been called up through her own (albeit "other") experience of dispossession, and through her adoption of a bodily proximity to Czech stories of suffering. Frank claims that "[1]iving for others means placing one's self and body within the "community of pain"” (p. 37 in Frank 1995), and we have seen that this position corresponds to Germain's Ruth-like relationship to Czech stories and memories. I have argued that, although these stories do not "belong" to Germain according to traditional understandings of "identity" in familial or national terms, her writing transcends these boundaries to occupy a transnational position from which she writes out her solidarity with the suffering or "sick" body of the Czech nation, so that we can understand Germain's work as a "witness by adoption". Her writing explores the journey from sickness to health in a manner that once again corresponds to Frank's understanding of the quest narrative, whereby, "[t]he final stage [of the quest] is the return. The teller returns as one who is no longer ill but remains marked by illness [...]. This marked person lives in a world she has

\footnotetext{
14 Note that Frank borrows the phrase "road of trials" from Joseph Campbell (1972).
} 
travelled beyond, a status well-described by Joseph Campbell's phrase "master of the two worlds"” (p. 118 in Frank 1995). The position occupied by Ludvík at the end of Éclats demonstrates this possibility of "return", and thus perhaps is offered in the hope that the Czech nation, for whom Germain clearly evinces empathy, may also "travel beyond" the "kingdom of the sick", out of that "dusty waiting room of history" to which they had so long been consigned by oppressive historical and political events.

I have identified a shift in Germain's Czech writings, which move from her earlier texts in which the painful legacy of historical suffering is marked out on the wounded body (as we have seen in the limping figure of the weeping woman), to a perhaps more nuanced embodiment of pain which is still told "through the body" but in a language of illness and of travel which offers the possibility of health, even as it acknowledges the difficulty of the healing process. This shift in Germain's approach to writing out suffering suggests that her experience in Czechoslovakia has been a journey in itself and that her proximity to "l'altérité radicale" (p. 110 in Kristeva 1988) has wrought changes in the way in which Germain perceives and writes about the world. Germain's own journey of encounter with the Czech other is, I propose, embedded in Prokop's own encounters and in the end of his textual journey in Immensités, which is marked by a literal journey, by tram, into the night:

Prokop louvoyait dans la rumeur de la ville, dans les remous chatoyants du réel, avec la nuit en poupe et l'inconnu en proue [...]. Prokop se sentait pleinement le frère de cet enfant à tête folle, au cœur volage et aux pas trébuchants, - l'humanité, sa sœur prodigue (p. 194 in Germain 1993a).

Prokop drifted on the murmuring swell of the world, on the sparkling eddies of reality, with the night at his stern and the unknown uncharted ahead of him... Prokop felt a true sense of kinship with that child he had met whose head was full of crazy ideas, whose heart was fickle, and who walked with a faltering step, - humanity was his prodigal sister.

Ultimately, then, Germain's Czech novels posit that the voyage from (figurative) sickness to health is also a voyage out of the confinement of the self (whether that is understood on individual terms, or in terms of a totalitarian divorce of a nation from the world), to a renunciation of "indifférence" and towards the "immensité" of integration with the world, with the other, with "l'humanité, sa sœur prodigue" [humanity, [our] prodigal sister] in all its alterity. Germain's texts move in various ways between, in terms of Campbell's metaphor, "two worlds", crossing and recrossing the borders between France and Czechoslovakia, East and West, self and other, the kingdoms of the well and of the sick; along the way, her writing negotiates the boundaries between forgetting and memory, silence and speech, pain and recovery. Whilst Germain's work acknowledges the impossibility of "knowing" the pain that is suffered by the other, through its use of the body it simultaneously constitutes an act of transnational "witness by adoption" to the immensity of such suffering. 
Open Access This article is distributed under the terms of the Creative Commons Attribution 4.0 International License (http://creativecommons.org/licenses/by/4.0/), which permits unrestricted use, distribution, and reproduction in any medium, provided you give appropriate credit to the original author(s) and the source, provide a link to the Creative Commons license, and indicate if changes were made.

\section{References}

Badré, Sabine. 2003. L'épiphanie ou la quête du visage dans La Pleurante des rues de Prague et Éclats de sel. In Sylvie Germain: Rose des vents et de l'ailleurs, ed. Toby Garfitt, 109-117. Paris: L'Harmattan.

Boblet, Marie-Hélène. 2008. Implication éthique et politique, d'Immensités à Magnus. In L'Univers de Sylvie Germain: Actes du colloque de Cerisy, 22-29 août 2007, ed. Alain Goulet, 55-67. Caen: Presses universitaires de Caen.

Butor, Michel. 1964. Essais sur le roman. Paris: Gallimard.

Campbell, Joseph. 1972. The hero with a thousand faces, 1949. Princeton: Princeton University Press. (first publ).

Cavarero, Adriana. 2000. Relating narratives: Storytelling and selfhood (trans: Kottman, Paul A.). London and New York: Routledge.

Davis, Colin. 1996. Levinas: An introduction. Oxford: Polity Press.

Davis, Colin. 2011. Trauma and ethics: Telling the other's story. In Other people's pain: Narratives of trauma and the question of ethics, ed. Martin Modlinger, and Philipp Sonntag, 19-42. Oxford: Peter Lang.

Diatkine, Anne. 1998. Tobie or not Tobie. Libération 30: lv-lvi.

Dotan, Isabelle. 2009. Les clairs-obscurs de la douleur: Regards sur l'œuvre de Sylvie Germain. Namur: Les Éditions namuroises.

Dotan, Isabelle, and Jacqueline Michel. eds. 2006. Sylvie Germain et son æeuvre. Bucharest: Samuel Tastet Éditeur.

Esbenshade, Richard S. 1995. Remembering to forget: memory, history, national identity in postwar EastCentral Europe. Representations 49(Winter): 72-96.

Felman, Shoshana. 1992. Education and crisis, or the vicissitudes of teaching. In Testimony: Crises of witnessing in literature, psychoanalysis, and history, ed. Shoshana Felman, and Dori Laub, 1-56. New York: Routledge.

Frank, Arthur. 1995. The wounded storyteller: Body, illness, and ethics. Chicago and London: University of Chicago Press.

Garfitt, Toby. ed. 2003. Sylvie Germain: Rose des vents et de l'ailleurs. Paris: L'Harmattan.

Garfitt, Toby. 2008. Sylvie Germain et Emmanuel Levinas. In L'Univers de Sylvie Germain: Actes du colloque de Cerisy, 22-29 août 2007, ed. Alain Goulet. Caen: Presses universitaires de Caen.

Germain, Sylvie. 1985. Le Livre des nuits. Paris: Gallimard.

Germain, Sylvie. 1991. L'Enfant Méduse. Paris: Gallimard.

Germain, Sylvie. 1992. La Pleurante des rues de Prague. Paris: Gallimard.

Germain, Sylvie. 1993a. Immensités. Paris: Gallimard.

Germain, Sylvie. 1993b. The Weeping Woman on the Streets of Prague (trans. from La Pleurante des rues de Prague by Judith Landry). Sawtry: Dedalus.

Germain, Sylvie. 1996. Éclats de sel. Paris: Gallimard.

Germain, Sylvie. 1998a. Bohuslav Reynek à Petrkov: Un nomade en sa demeure. St-Cyr-sur-Loire: Christian Pirot Éditeur.

Germain, Sylvie. 1998b. Infinite Possibilities (trans. from Immensités by Elizabeth Nash). Sawtry: Dedalus.

Germain, Sylvie. 2003. Invitation to a Journey (trans. from Éclats de sel by Christine Donougher). Sawtry: Dedalus.

Germain, Sylvie. 2006. Traces et réverbérations de l'œuvre de Levinas'. Audio archives at the Centre Pompidou, Bibliothèque publique d'information. http://archives-sonores.bpi.fr/index.php?urlaction= doc\&id_doc=2175\&rang=1. Accessed 28 Jan 2014.

Glaiman, Dorothy. 2005. Au service des mots: Interview de Sylvie Germain. In Le Figaro. www.evene. lefigaro.fr/livres/actualite/interview-de-sylvie-germain-204.php. Accessed 05 Oct 2014. 
Goulet, Alain. 2006. Sylvie Germain: Euvre romanesque. Un monde de cryptes et de fantômes. Paris: L'Harmattan.

Goulet, Alain. ed. 2008. L'Univers de Sylvie Germain: Actes du colloque de Cerisy, 22-29 août 2007. Caen: Presses universitaires de Caen.

Hartman, Geoffrey. 1996. The longest shadow: In the aftermath of the Holocaust. New York: Palgrave Macmillan.

Hawkesworth, Celia. ed. 2001. A history of Central European women's writing. Basingstoke and New York: Palgrave.

Hirsch, Marianne. 2001. Surviving images: Holocaust photographs and the work of postmemory. The Yale Journal of Criticism 14(1): 5-37.

Keller, Ursula. 2004. Writing Europe. In Writing Europe: What is European about the literatures of Europe? Essays from 33 European Countries, ed. Ursula Keller and Ilma Rakusa (trans. Andrew Gane). Budapest and New York: Central European University Press. pp. 1-20. Volume originally publ. in German as Europa Schreibt. Was ist das Europäische an den Literaturen Europas? Hamburg: Körber-Stiftung, 2003.

Kramsch, Claire. 2006. The traffic in meaning. Asia Pacific Journal of Education 26(1): 99-104.

Kristeva, Julia. 1988. Étrangers à nous-mêmes. Paris: Gallimard.

Kundera, Milan. 1987. Le Livre du rire et de l'oubli. Paris: Gallimard.

Levinas, Emmanuel. 1971. Totalité et infini: Essais sur l'extériorité. Paris: Livre de Poche.

Levinas, Emmanuel. 1998. Useless suffering. In Entre nous: On thinking of the other (trans. Michael B. Smith and Barbara Harshav). London: Athlone Press.

Magill, Michèle. 1999. Entretien avec Sylvie Germain. The French Review 73(2): 334-340.

Marven, Lyn. 2005. Body and narrative in contemporary literatures in German: Herta Müller, Libuše Moníková, Kerstin Hensel. Oxford: Clarendon Press.

Paver, Chloe. 2010. From monuments to installations: Aspects of memorialization in historical exhibitions about the national socialist era. In Memorialization in Germany since 1945, ed. Bill Niven, and Chloe Paver, 253-264. Basingstoke: Palgrave Macmillan.

Pirard, Anne-Marie. 1992. Sylvie Germain. Indications 6-11.

Poulouin, Gérard. 2008. Des voix singulières à Prague. In L'Univers de Sylvie Germain: Actes du colloque de Cerisy, 22-29 août 2007, ed. Alain Goulet, 41-53. Caen: Presses universitaires de Caen.

Richter, Václav. 2005. Sylvie Germain: "Mon imaginaire s'est nourri de Prague et de la Bohême”. Radio Prague. http://www.radio.cz/fr/rubrique/literature/sylvie-germain-mon-imaginaire-sest-nourri-deprague-et-de-la-boheme. Accessed 11 Nov 2013.

Roche, Anne. 2008. Le Rapport à la bibliothèque. In L'Univers de Sylvie Germain: Actes du colloque de Cerisy, 22-29 août 2007, ed. Alian Goulet, 29-40. Caen: Presses universitaires de Caen.

Said, Edward. 2001. Reflections on exile and other literary and cultural essays. London: Granta.

Sontag, Susan. 1983. Illness as Metaphor. London: Penguin.

Sontag, Susan. 2003. Regarding the pain of others. London: Penguin.

Trezise, Thomas. 2002. The question of community in Charlotte Delbo's Auschwitz and after. Modern Language Notes 117(4): 858-886.

Willoughby, Ian. 2015. Prague's 19th century Těšnov station remembered on 30th anniversary of demolition. Radio Prague. http://radio.cz/en/section/curraffrs/pragues-19th-century-tesnov-stationremembered-on-30th-anniversary-of-demolition. Accessed 03 May 2015.

Winstone, Martin. 2010. The Holocaust sites of Europe: An historical guide. I.B.Tauris: London and New York.

Young, Elizabeth. 1993. Sylvie Germain-Interview with Elizabeth Young. In The Weeping Woman on the Streets of Prague (trans. Judith Landry), 7-13. Sawtry: Dedalus.

Clare Horáčková is currently an Associate Lecturer in French at the University of Exeter, UK. Her research interests are in recent French and Francophone literatures, with a particular focus on the narration of traumatic memories and the relationship between self and other. 